\title{
Changes in Streamflow Characteristics in Wisconsin as Related to Precipitation and Land Use
}

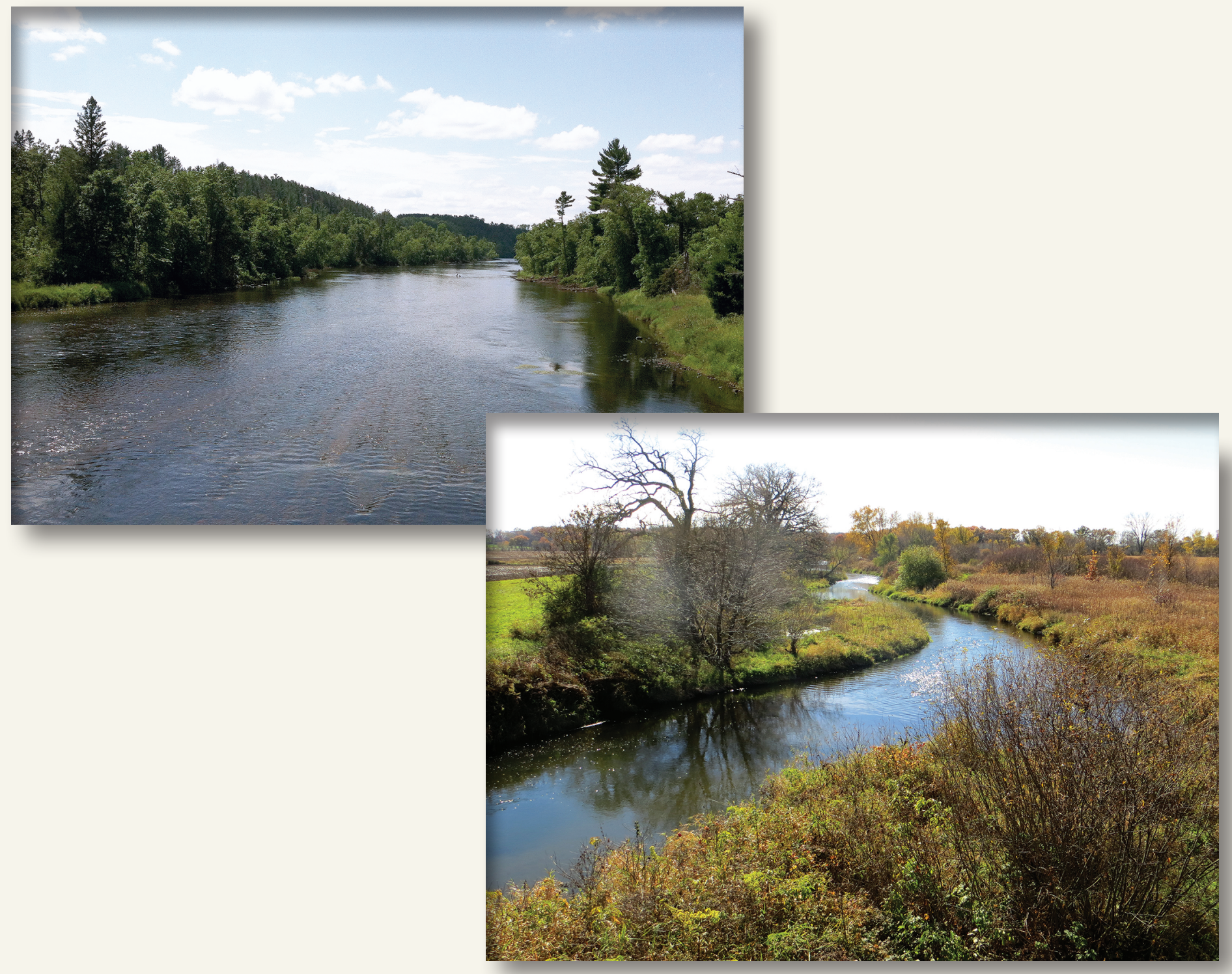

Scientific Investigations Report 2015-5140

Version 1.1 January 2016 
Cover photographs. The St. Croix River at Danbury, Wisconsin by Josef Schuler (upper left), and the Sugar River near Belleville, Wisconsin by Warren Gebert (lower right). 


\section{Changes in Streamflow Characteristics in Wisconsin as Related to Precipitation and Land Use}

By Warren A. Gebert, Herbert S. Garn, and William J. Rose

Scientific Investigations Report 2015-5140

Version 1.1 January 2016 


\section{U.S. Department of the Interior \\ SALLY JEWELL, Secretary}

\section{U.S. Geological Survey \\ Suzette M. Kimball, Director}

\section{U.S. Geological Survey, Reston, Virginia:}

First release: 2016

Revised: January 26, 2016 (ver. 1.1)

For more information on the USGS - the Federal source for science about the Earth, its natural and living resources, natural hazards, and the environment-visit http://www.usgs.gov or call 1-888-ASK-USGS.

For an overview of USGS information products, including maps, imagery, and publications, visit http://www.usgs.gov/pubprod/.

Any use of trade, firm, or product names is for descriptive purposes only and does not imply endorsement by the U.S. Government.

Although this information product, for the most part, is in the public domain, it also may contain copyrighted materials as noted in the text. Permission to reproduce copyrighted items must be secured from the copyright owner.

Suggested citation:

Gebert, W.A., Garn, H.S., and Rose, W.J., 2016, Changes in streamflow characteristics in Wisconsin as related to precipitation and land use (ver. 1.1, January 26, 2016): U.S. Geological Survey Scientific Investigations Report 2015-5140, 23 p., and 1 appendix, http://dx.doi.org/10.3133/sir20155140.

ISSN 2328-031X (print) ISSN 2328-0328 (online) 


\section{Contents}

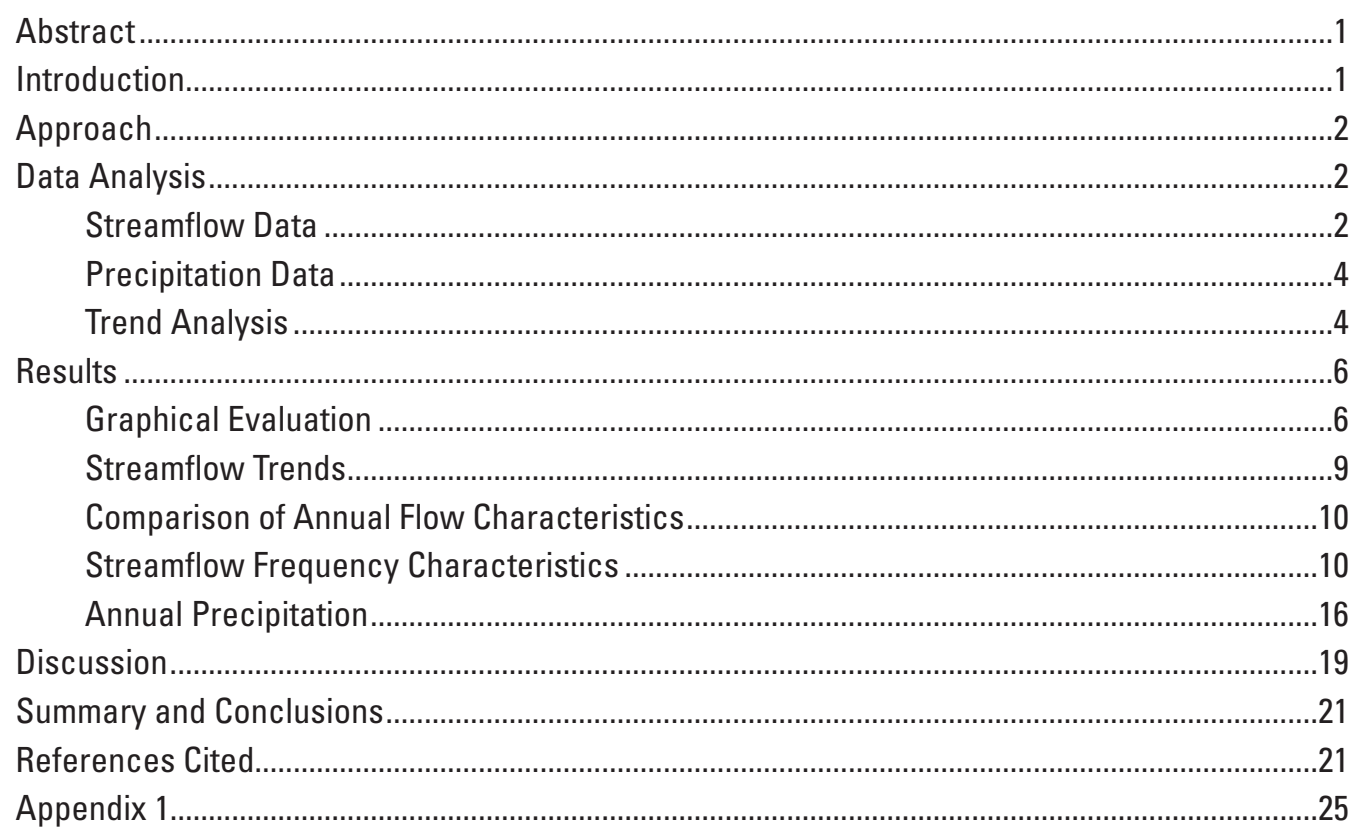

\section{Figures}

1. Map showing location of major river drainage basins and streamflow-gaging stations in Wisconsin.

2. Map showing nine climatic divisions (determined by the National Weather Service) and streamflow-gaging stations in Wisconsin.

3. Graphs showing data for Sugar River near Brodhead, Wisconsin, for the period 1915-2008. A, Annual 7-day low flow. B, Annual average flow. $C$, Annual flood peak discharge. $D$, Annual average precipitation for climatic division 8

4. Graphs showing data for St. Croix River near Danbury, Wisconsin, for the period 1915-2008. A, Annual 7-day low flow. B, Annual average flow. C, Annual flood peak discharge. $D$, Annual average precipitation for climatic division 1.

5. Graphs showing percent change in annual streamflow characteristics and annual precipitation between the 1915-68 and 1969-2008 periods with significant differences ( $p$-values less than 0.05 ) indicated by an asterisk.

6. Graph showing changes in annual 7-day low flow from 1915-68 to 1969-2008 related to forest cover in Wisconsin

7. Graphs showing comparison of changes in streamflow frequency characteristics in Wisconsin rivers between the 1915-68 and 1969-2008 periods.

8. Graph showing average percent change in monthly precipitation for nine National Weather Service Climatic Divisions in Wisconsin from 1915-68 to 1969-2008.

9. Graphs showing percentage changes in $A$, annual 7-day low flow; $B$, average annual flow; and $C$, annual flood peak discharge in relation to percentage change in annual precipitation from 1915-68 to 1969-2008 in Wisconsin

10. Graph showing annual streamflow characteristics for Fox River at Berlin, Wisconsin, for the period 1898-2008 


\section{Tables}

1. Selected streamflow-gaging stations in major river basins of Wisconsin

2. Selected streamflow-gaging stations in Wisconsin and corresponding Kendall tau and $p$-value of trends for annual 7-day low flow, annual average flow, annual flood peak discharge, and annual average precipitation, 1915-2008 period with statistically significant values of $p$ less than 0.05 in bold and highlighted.

3. Selected streamflow-gaging stations in Wisconsin and corresponding Kendall tau and $p$-values of trends for annual 7-day low flow, annual average flow, annual flood peak discharge, and annual average precipitation for the 1969-2008 period with statistically significant values of $p$ less than 0.05 in bold and highlighted.

4. Summary of percent changes from 1915-68 to 1969-2008 in annual streamflow characteristics and annual precipitation in 14 watersheds.

5. Comparison of streamflow frequency characteristics for various periods at four streamflow-gaging stations in Wisconsin.

6. Average annual precipitation, in inches, for streamflow-gaging station watersheds in Wisconsin for the periods 1915-68 and 1969-2008 and percent increase between periods

\section{Conversion Factors}

[Inch/Pound to International System of Units]

\begin{tabular}{lcl}
\hline \multicolumn{1}{c}{ Multiply } & By & \multicolumn{1}{c}{ To obtain } \\
\hline inch (in.) & Length & \\
inch (in.) & 2.54 & centimeter $(\mathrm{cm})$ \\
& 25.4 & millimeter $(\mathrm{mm})$ \\
\hline square mile $\left(\mathrm{mi}^{2}\right)$ & Area & \\
square mile $\left(\mathrm{mi}^{2}\right)$ & 259.0 & hectare $(\mathrm{ha})$ \\
& 2.590 & square kilometer $\left(\mathrm{km}^{2}\right)$ \\
\hline cubic foot per second $\left(\mathrm{ft}^{3} / \mathrm{s}\right)$ & Flow rate & \\
inch per hour $(\mathrm{in} / \mathrm{h})$ & 0.02832 & cubic meter per second $\left(\mathrm{m}^{3} / \mathrm{s}\right)$ \\
\hline
\end{tabular}

Temperature in degrees Fahrenheit $\left({ }^{\circ} \mathrm{F}\right)$ may be converted to degrees Celsius $\left({ }^{\circ} \mathrm{C}\right)$ as:

$$
{ }^{\circ} \mathrm{C}=\left({ }^{\circ} \mathrm{F}-32\right) / 1.8 \text {. }
$$




\title{
Changes in Streamflow Characteristics in Wisconsin as Related to Precipitation and Land Use
}

\author{
By Warren A. Gebert, Herbert S. Garn, and William J. Rose
}

\section{Abstract}

Streamflow characteristics were determined for 15 longterm streamflow-gaging stations for the periods 1915-2008, 1915-68, and 1969-2008 to identify trends. Stations selected represent flow characteristics for the major river basins in Wisconsin. Trends were statistically significant at the 95 percent confidence level at 13 of the 15 streamflow-gaging stations for various streamflow characteristics for 1915-2008. Most trends indicated increases in low flows for streams with agriculture as the dominant land use.

The three most important findings are: increases in low flows and average flows in agricultural watersheds, decreases in flood peak discharge for many streams in both agricultural and forested watersheds, and climatic change occurred with increasing annual precipitation and changes in monthly occurrence of precipitation.

When the 1915-68 period is compared to the 1969-2008 period, the annual 7-day low flow increased an average of 60 percent for nine streams in agricultural areas as compared to a 15 percent increase for the five forested streams. Average annual flow for the same periods increased 23 percent for the agriculture streams and 0.6 percent for the forested streams. The annual flood peak discharge for the same periods decreased 15 percent for agriculture streams and 8 percent for forested streams. The largest increase in the annual 7-day low flow was 117 percent, the largest increase in annual average flow was 41 percent, and the largest decrease in annual peak discharge was 51 percent.

The trends in streamflow characteristics affect frequency characteristics, which are used for a variety of design and compliance purposes. The frequencies for the 1969-2008 period were compared to frequencies for the 1915-68 period. The 7-day, 10-year $\left(\mathrm{Q}_{7,10}\right)$ low flow increased 91 percent for nine agricultural streams, while the five forested streams had an increase of 18 percent. The 100-year flood peak discharge decreased an average of 15 percent for streams in the agriculture area and 27 percent for streams in the forested area.

Increases in low flow for agriculture streams are attributed to changes in agricultural practices and land use as well as increased precipitation. The decrease in annual flood peak discharge with increased annual precipitation is less clear, but is attributed to increased infiltration from changes in agricultural practices and climatic changes. For future low-flow studies, the 1969-2008 period should be used to determine low-flow characteristics since it represents current (2014) conditions and was generally free of significant trends.

\section{Introduction}

The purpose of this study was to determine trends in streamflow characteristics for streams in Wisconsin and select a period for future low-flow studies that represents current (2014) streamflow conditions. Previous low-flow studies in the 1970s and 1980s determined low-flow characteristics at sewage-treatment and industrial plants for compliance with Wisconsin water-quality standards (Gebert and Holmstrom, 1977; Gebert, 1978, 1979a, 1979b, 1980, 1982). A report on streamflow trends in southwestern Wisconsin (Gebert and Krug, 1996) raised questions about how well low-flow characteristics in previous reports represent current streamflow conditions. They found significant trends in low- and highflow characteristics for streams where the predominant land use was agriculture. A trend analysis for 20 streamflow-gaging stations indicated that low-flow characteristics were increasing and peak flow characteristics were decreasing for agriculturedominated streams but not for streams where forest was the predominant land use. The trends were attributed mainly to improved agricultural practices. Most of the changes occurred after implementation of improved U.S. Soil Conservation Service agricultural practices starting in the 1940s (Trimble, 1981; Trimble and Lund, 1982; Potter, 1991; Krug, 1996). A trend analysis for the same stations for the period 1970-92 found no trends for 18 of the 20 stations. Selecting periods with no apparent trends will result in more accurate estimates of low-flow characteristics at sewage-treatment and industrial plants for compliance with Wisconsin water-quality standards.

A number of studies have evaluated changes in streamflow characteristics and have attempted to relate the changes to climate or land use. McCabe and Wolock (2002) looked at 400 gaging station sites in the conterminous United States measured during the period 1944-99 and found statistically 
significant changes in low and median flows. In the Midwest, including Wisconsin, the increase in flows was notable around 1970. The changes were reported to appear as a step change rather than a gradual trend and coincided with an increase in precipitation. A possible reason for the increase was the increase in fall and winter precipitation. In addition it was stated that improvements in agricultural and land management practices contributed to the changes.

Hodgkins and Dudley (2006), and Hodgkins and others (2007), in studies of historical changes in streamflow and precipitation in the Great Lakes Basin, found that annual runoff and mean annual 7-day low flow increased for selected streamflow gaging stations from 1955 to 2004 . Annual precipitation also increased over this time period and from 1915 to 2004.

In a study of streamflow in the driftless area of southwestern Wisconsin, Juckem and others (2008) evaluated the effects on streamflow due to climatic and land management changes by comparing volumetric changes in the hydrologic budget before and after 1970. They found increases in baseflow and annual flow with a decrease in stormflow. They concluded the timing of the hydrologic changes coincides with changes in precipitation and that the magnitude of the changes was likely amplified by changes in agricultural land management practices.

The emphasis of the Gebert and Krug (1996) study was for streams in southwestern Wisconsin. This report provides better statewide coverage with trends evaluated for selected streams in each of the 12 major river basins in Wisconsin. This report includes precipitation analysis from stations representing the nine climatic divisions in Wisconsin. The previous study also used streamflow-gaging-station data from different periods of record, while this study used a common time period to reduce differences that occur from using different periods.

\section{Approach}

Wisconsin has a large streamflow database available from U.S. Geological Survey (USGS) streamflow-gaging stations. In 2008, 155 streamflow-gaging stations were operated by the USGS in Wisconsin that provided daily streamflow data described in USGS annual data reports, "Water Resources Data, Wisconsin" (U.S. Geological Survey, 1976-2006; U.S. Geological Survey 2007-9). Many of the streamflowgaging stations have long-term records, with several records going back to the 1890s. Many of these are on unregulated or minimally regulated streams and therefore provide an excellent database for determining long-term streamflow characteristics and streamflow trends.

This study computed streamflow characteristics for longterm streamflow-gaging stations with no or minimal regulation to evaluate if changes have occurred. The streamflow-gaging stations selected for analysis are shown in figure 1. Five of the 15 selected stations are part of the USGS Hydro-Climatic Data Network (HCDN) that was established in 2011 (Falcone, 2011;
Lins, 2012). The network consists of 743 streamflow-gaging stations nationally. The purpose of the network is to provide a streamflow dataset suitable for analyzing hydrologic variations and trends in a climatic context. The 10 stations used in the study that are not part of HCDN meet the criteria outlined by Falcone except for the visual screening by satellite imagery for the presence of human activities

\section{Data Analysis}

\section{Streamflow Data}

Streamflow data analysis consisted of the following:

1. Fifteen streamflow-gaging stations were selected for the analysis. At least 1 long-term streamflow-gaging station was selected for each of the 12 major river basins in Wisconsin.

2. The streamflow characteristics selected for analysis were the annual 7-day low flow, annual average flow and annual flood peak discharge. The 1915-2008 period was selected because it represented the longest period where most of the major river basins had streamflow data available. Some major river basins did not have a streamflow-gaging station with data for the entire period but did have streamflow-gaging stations with data for most of that period. Missing annual 7-day low flow and annual average flow was estimated by correlation analysis with nearby streamflow-gaging stations. Annual flood peak discharge data were not estimated for missing years because correlations did not provide good relations. Correlation coefficients associated with the correlation analysis for annual 7-day low flow and annual average flow were generally greater than 0.80 . A minimum of 0.60 was used for the correlation to be acceptable for extending the record. No correlation for the annual flood peak discharges had a correlation of 0.50 or greater.

3. Graphs of annual streamflow characteristics were made for all 15 streamflow-gaging stations to identify trends and to aid in selecting a common long-term period that best represented current streamflow conditions.

Table 1 lists the streamflow-gaging stations used in the study as well as their years of recorded data, years of estimated record, drainage area and primary land use characteristics. The streams were divided into two classes: those that had greater than 50 percent forest cover were classified as forested; and those classified as agricultural had more than 49 percent agricultural lands and less than 50 percent forest cover. Five of the basins were classified as forested and 10 as agricultural. Land use cover percentages were determined by use of the 2002 National Land Cover Dataset (NLCD). The percent forest cover in table 1 includes the percent of wooded wetland as determined in NLCD. It was assumed that changes in land use during the period of the study would not have changed how streams were classified. 


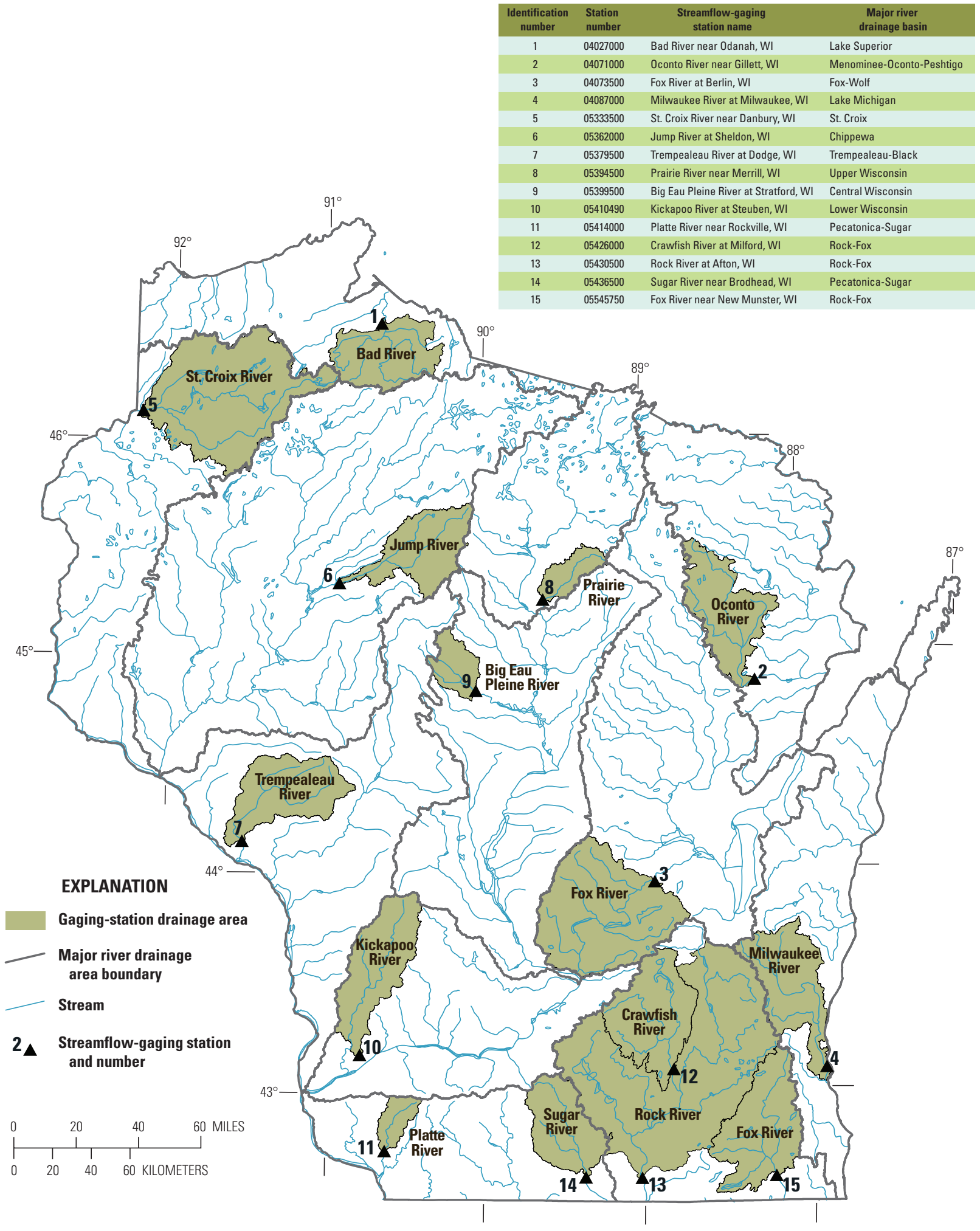

Figure 1. Location of major river drainage basins and streamflow-gaging stations in Wisconsin. 
Table 1. Selected streamflow-gaging stations in major river basins of Wisconsin. Land cover percentages determined by 2002 National Land Cover Dataset.

$\left[\mathrm{mi}^{2}\right.$, square miles]

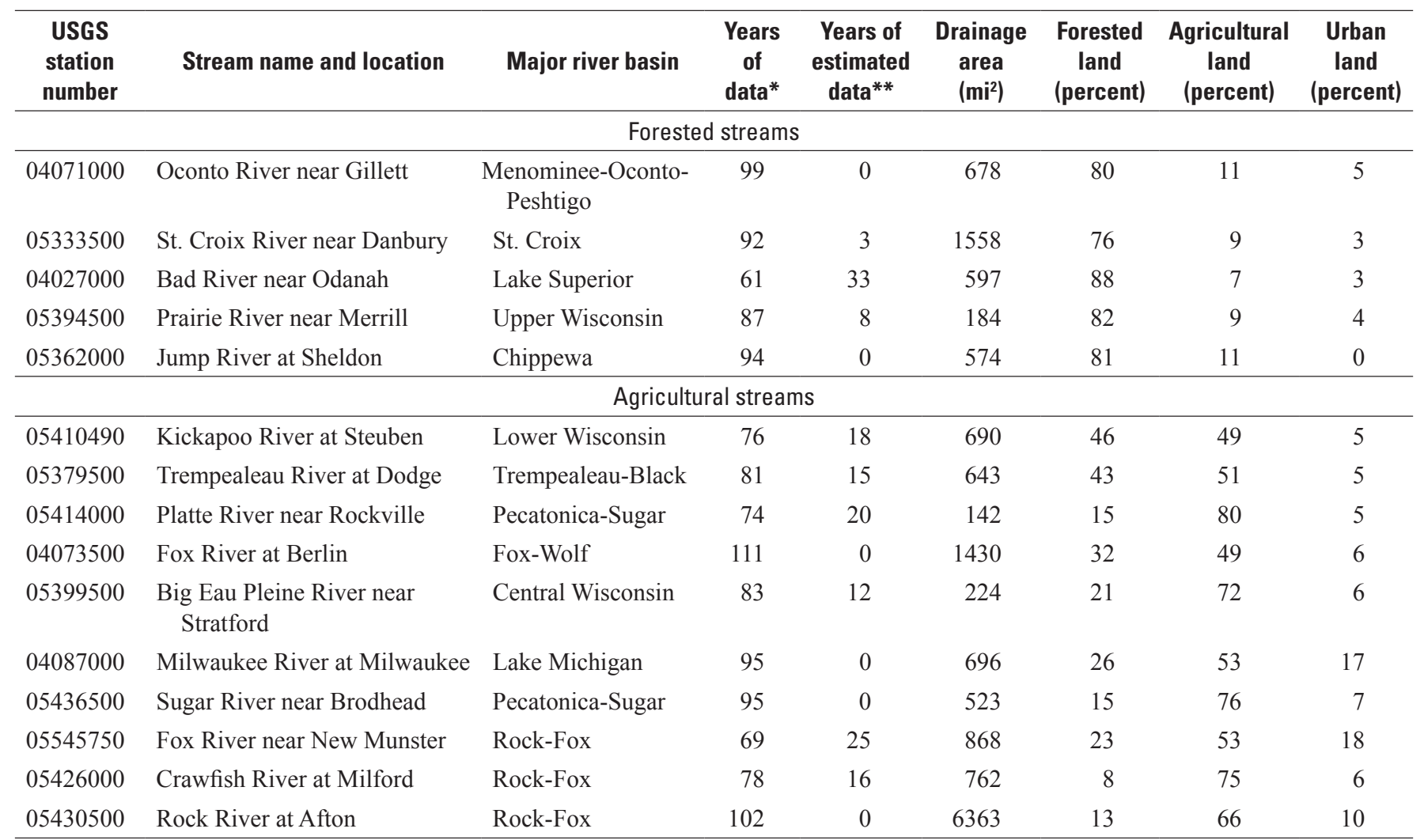

*Years of recorded data from beginning of station through 2008.

${ }^{* * *}$ Number of years data were estimated in the 93-year period 1915-2008.

\section{Precipitation Data}

Precipitation data were obtained from the National Weather Service Midwestern Regional Climate Center (MRCC; U.S. Department of Commerce-National Oceanic and Atmospheric Administration, 2009). The MRCC partitions the State into nine divisions, for which annual and monthly average precipitation data are summarized from the 176 weather stations in the State. The weather stations are distributed throughout the State with each division having precipitation data from at least 10 weather stations. The divisions are discussed on the State Climatology Office Web site (http://www. aos.wisc.edu/ sco/clim-history/division/index.html). The precipitation data for the 15 streamflow-gaging stations were determined from the division in which they are located (fig. 2). If the drainage area was in two or more divisions, the monthly and annual values for the watershed were weighted according to the percentage of the drainage area in each division.

\section{Trend Analysis}

Time trends of the streamflow characteristics at all the streamflow-gaging stations and corresponding precipitation on the watershed were investigated by computing the Kendall's tau correlation coefficient (Kendall, 1970; Conover, 1971). The Kendall tau is a nonparametric test for trends. Kendall's tau measures trend strength and is appropriate for variables like streamflow characteristics that have skewness and are not normally distributed. Tau values can range from -1 to +1 . A value of -1 results when each succeeding value is less than the one previous; a value of +1 results when each value is greater than the one previous. The expected value of the tau for records with no trend is zero. A random distribution of values can result in an observable trend, but the chance of this occurring can be evaluated statistically. In general, the more Kendall's tau deviates from zero, the more likely it is that a trend exists. 


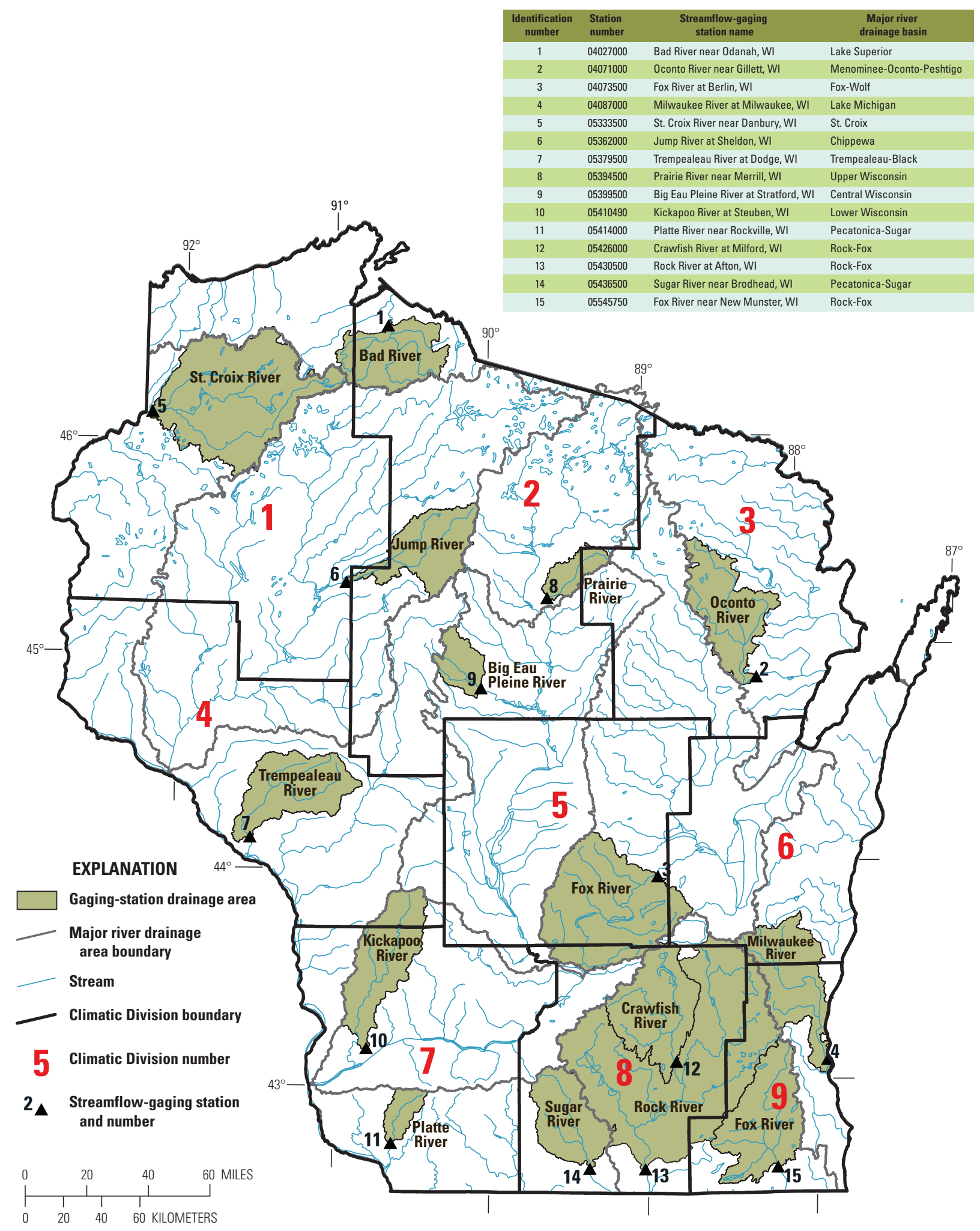

Figure 2. Nine climatic divisions (determined by the National Weather Service) and streamflow-gaging stations in Wisconsin. 
The tests for significance shown in table 2 are the p-values corresponding to Kendall's tau. Online software was used to calculate the statistics (Wessa, 2012). A p-value of 0.05 means there is a 95 percent assurance that the trend is real or there is a 5 percent chance that the apparent trend is due to random chance. A trend was considered significant if the p-value was 0.05 or less.

Table 2. Selected streamflow-gaging stations in Wisconsin and corresponding Kendall tau and p-value of trends for annual 7-day low flow, annual average flow, annual flood peak discharge, and annual average precipitation, 1915-2008 period with statistically significant values of $p$ less than 0.05 in bold and highlighted.

$[<$, less than $]$

\begin{tabular}{|c|c|c|c|c|c|c|c|c|c|}
\hline \multirow{2}{*}{$\begin{array}{l}\text { USGS } \\
\text { station } \\
\text { number }\end{array}$} & \multirow{2}{*}{ Stream name and location } & \multicolumn{2}{|c|}{$\begin{array}{c}\text { Annual } \\
\text { 7-day low flow }\end{array}$} & \multicolumn{2}{|c|}{$\begin{array}{c}\text { Annual } \\
\text { average flow }\end{array}$} & \multicolumn{2}{|c|}{$\begin{array}{c}\text { Annual } \\
\text { flood peak discharge }\end{array}$} & \multicolumn{2}{|c|}{$\begin{array}{c}\text { Annual } \\
\text { average precipitation }\end{array}$} \\
\hline & & Tau & $p$-value & Tau & p-value & Tau & p-value & Tau & p-value \\
\hline \multicolumn{10}{|c|}{ Forested streams } \\
\hline 04071000 & Oconto River near Gillett & -0.017 & 0.804 & -0.115 & 0.102 & -0.166 & 0.019 & 0.120 & 0.090 \\
\hline 05333500 & St. Croix River near Danbury & 0.078 & 0.278 & 0.091 & 0.206 & 0.130 & 0.069 & 0.170 & 0.014 \\
\hline 05394500 & Prairie River near Merrill & -0.047 & 0.524 & -0.143 & 0.055 & -0.052 & 0.478 & 0.060 & 0.399 \\
\hline 05362000 & Jump River at Sheldon & 0.311 & $<0.001$ & -0.009 & 0.897 & -0.021 & 0.765 & 0.024 & 0.737 \\
\hline \multicolumn{10}{|c|}{ Agricultural streams } \\
\hline 05410490 & Kickapoo River at Steuben & 0.338 & $<0.001$ & 0.145 & 0.041 & -0.191 & $* 0.015$ & 0.161 & 0.022 \\
\hline 05379500 & Trempealeau River at Dodge & 0.500 & $<0.001$ & 0.265 & $<0.001$ & -0.113 & $* 0.140$ & 0.184 & 0.009 \\
\hline 04087000 & Milwaukee River at Milwaukee & 0.378 & $<0.001$ & 0.167 & 0.018 & -0.013 & 0.860 & 0.197 & 0.005 \\
\hline 05436500 & Sugar River near Brodhead & 0.375 & $<0.001$ & 0.145 & 0.038 & -0.191 & 0.007 & 0.198 & 0.005 \\
\hline 05545750 & Fox River near New Munster & 0.316 & $<0.001$ & 0.155 & 0.030 & 0.103 & $* 0.214$ & 0.200 & 0.005 \\
\hline 05426000 & Crawfish River at Milford & 0.310 & $<0.001$ & 0.142 & 0.045 & -0.010 & *0.898 & 0.199 & 0.005 \\
\hline 05430500 & Rock River at Afton & 0.145 & 0.040 & 0.188 & 0.008 & -0.057 & 0.418 & 0.200 & 0.005 \\
\hline
\end{tabular}

* For actual period of record, no estimated periods.

\section{Results}

Streamflow and precipitation data were evaluated by several methods to determine if changes or trends occurred.

\section{Graphical Evaluation}

Graphs of annual streamflow characteristics and annual precipitation data for the period 1915-2008 provided a means for evaluating the data to observe changes and also provided a least-square trendline as an indicator of possible trends. Examples of the plots for two streamflow-gaging stations are shown in figures 3 and 4 . The trend patterns were similar to those found by Gebert and Krug (1996). In agricultural areas (fig. 3), low flow is increasing and flood peak discharge is decreasing, while in the forested areas (fig. 4) there was no or little change in either low flow or flood peak discharge. That study concluded that the trends were mainly due to change in agricultural practices and land use that started to occur after 1940. Most of these changes occurred before the late 1960s (Potter, 1991; Trimble, 1981; Trimble and Lund, 1982). Some of the changes in agricultural practices that were found included contour-strip cropping, contour plowing, incorporation of crop residue into the soil, crop rotation, and increased depth of plowing. The primary land-use change was the conversion of steep hillsides from pasture to woodlots, which was especially important for streams in hilly southwestern Wisconsin. 
A. Annual 7-day low flow for the Sugar River near Brodhead

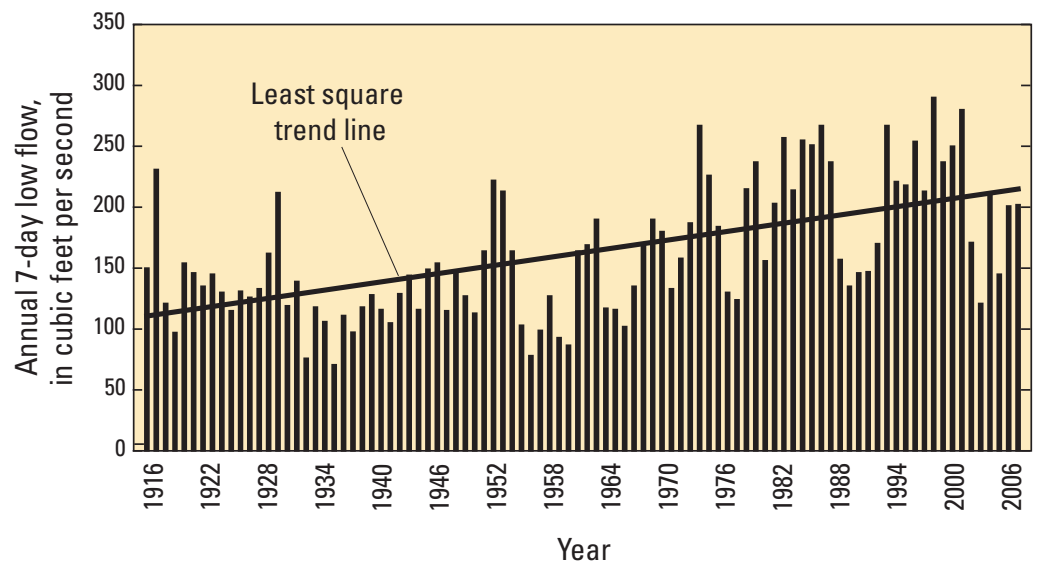

C. Annual flood peak discharge for the Sugar Rivernear Brodhead

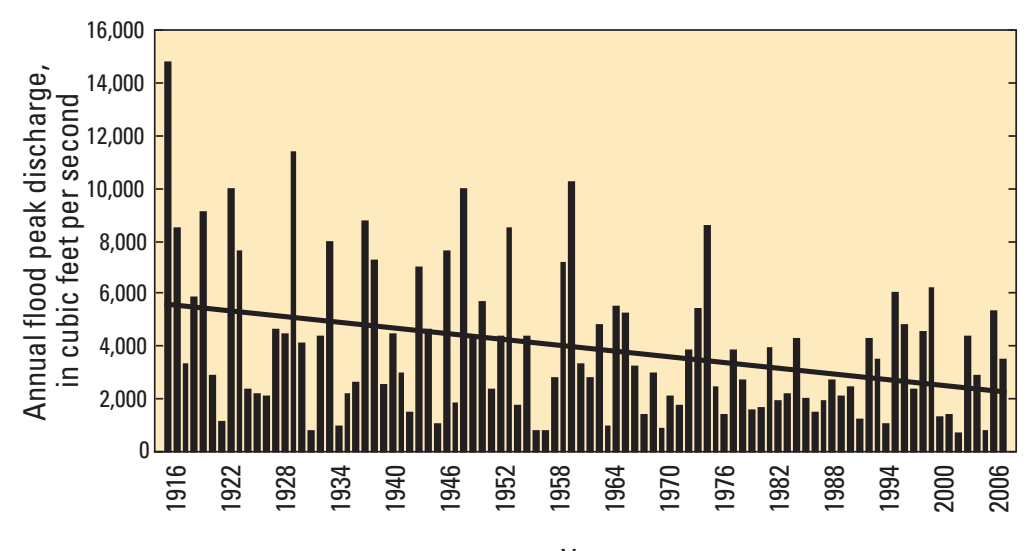

Year

B. Annual average flow for the Sugar River near Brodhead

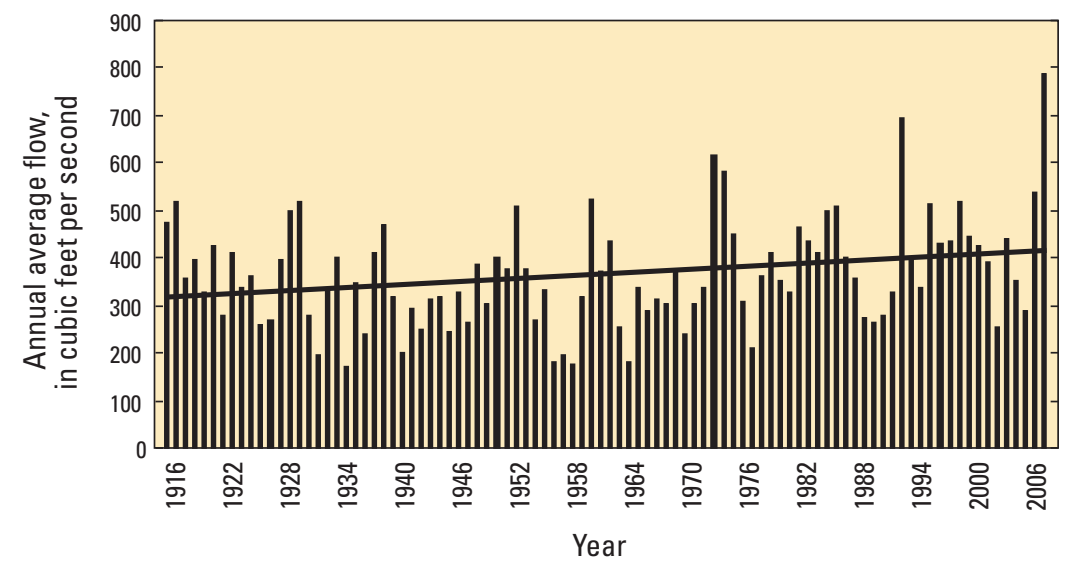

D. Annual average precipitation for Climatic Division 8

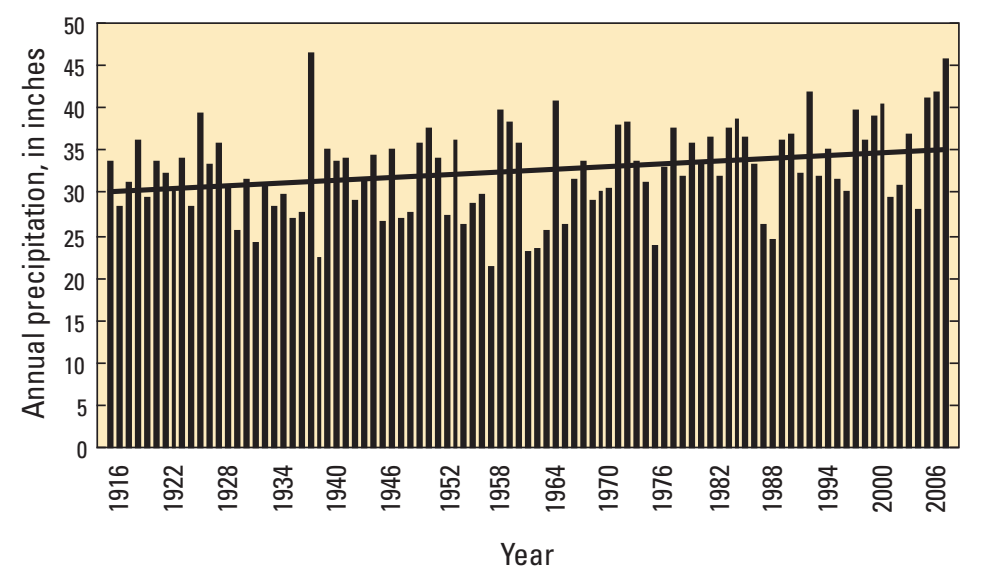

Figure 3. Data for Sugar River near Brodhead, Wisconsin, for the period 1915-2008. A, Annual 7-day low flow. B, Annual average flow. C, Annual flood peak discharge. $D$, Annual average precipitation for climatic division 8 . 
A. Annual 7-day low flow for the St. Croix River near Danbury

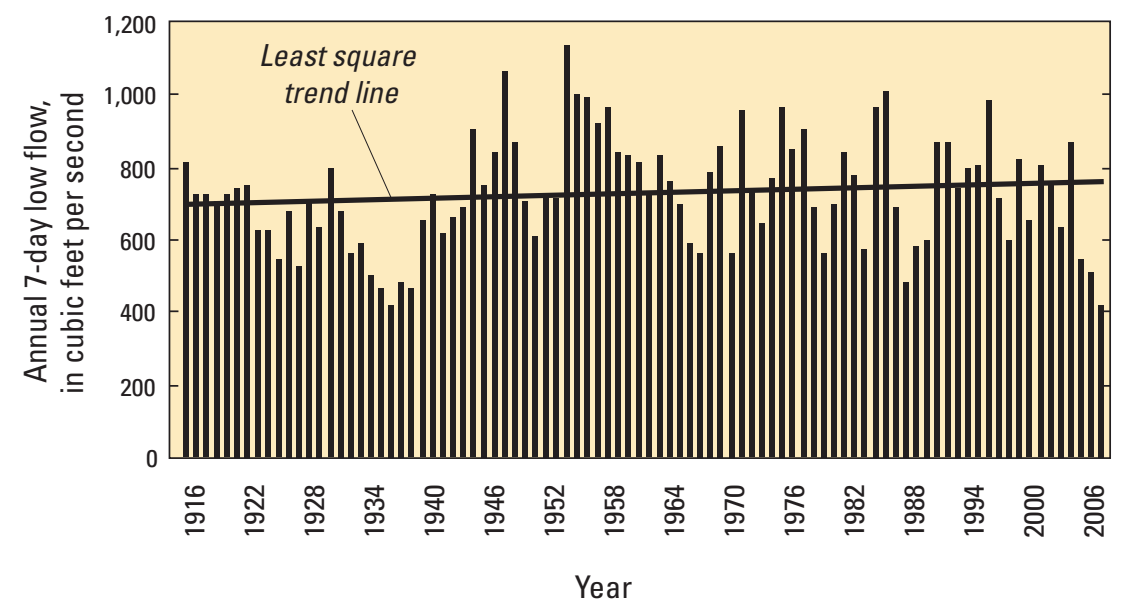

C. Annual flood peak discharge for the St. Croix River near Danbury

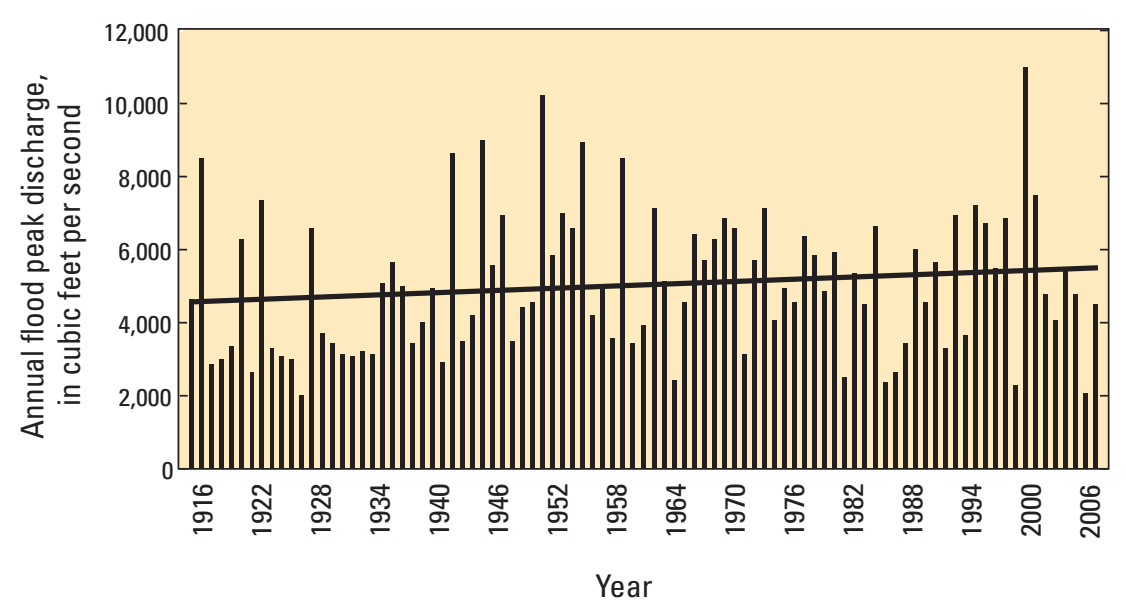

B. Average annual flow for the St. Croix River near Danbury

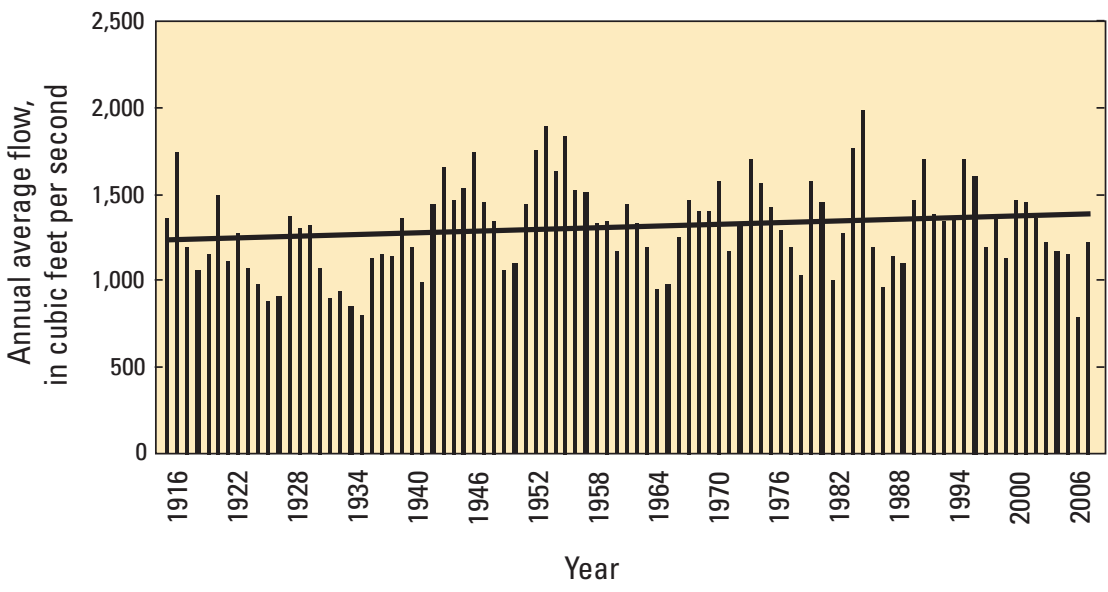

D. Annual average precipitation for Climatic Division 1

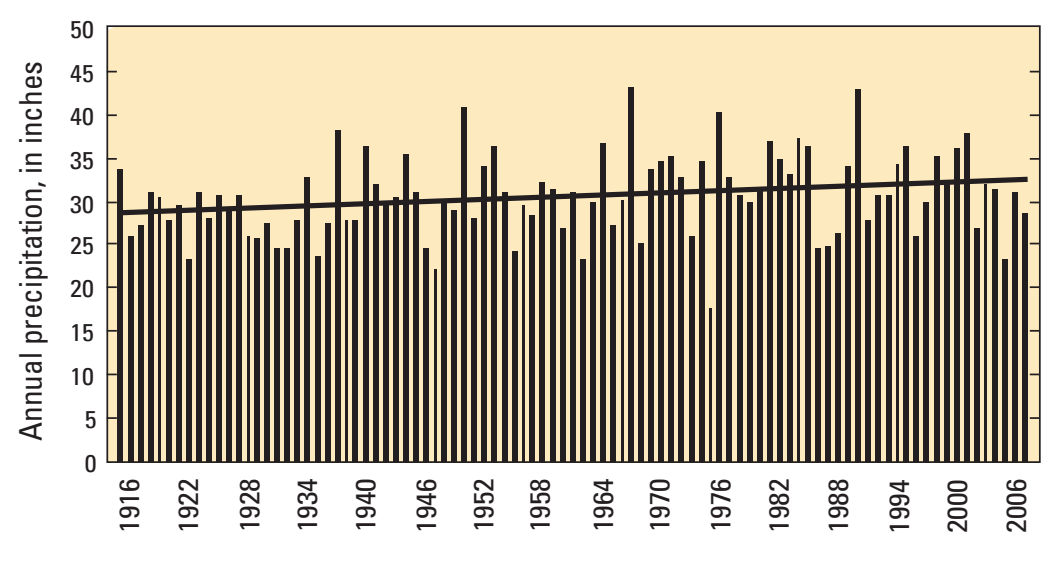

Year
Figure 4. Data for St. Croix River near Danbury, Wisconsin, for the period 1915-2008. A, Annual 7-day low flow. B, Annual average flow. C, Annual flood peak discharge. $D$, Annual average precipitation for climatic division 1. 
Based on this evaluation of the graphs for the 15 streamflow-gaging stations and the trend analysis done in Gebert and Krug (1996), which found no trend in 18 out of 20 streams for the period 1970-92, this report selected the 1969-2008 period as the period for comparison with the 1915-68 period.

\section{Streamflow Trends}

A trend analysis of the entire 1915-2008 period showed that the annual 7-day low flow generally increased in the agricultural watersheds but showed little change in the forested watersheds (table 2). Annual 7-day low flow increased significantly (p-values less than 0.05 ) in 9 of 10 streams in agricultural area watersheds. For the five forested streams, four had no significant trends, and one (Jump River at Sheldon) had a significant increase.

Annual average flow behaved similarly to annual 7-day low flow. Seven of the 10 agricultural streams had significant increasing trends. The forested streams had no significant trends.
Annual flood peak discharge had significant decreasing trends for 4 of the 10 agricultural streams. Four of the forested streams had no apparent trend, and one (Oconto River near Gillett) had a significant decreasing trend.

An example of the trends in an agricultural watershed is the Milwaukee River at Milwaukee. The p-values for the annual 7-day low flow and annual average flow were $<0.001$ and 0.018 , respectively, indicating significant trends despite having 17 percent urban area in its watershed; the p-value for the annual flood peak discharge was 0.860 , indicating an absence of trend. The St. Croix River near Danbury is an example of lack of trends in forested watersheds. The $\mathrm{p}$-value for the annual 7-day low flow was 0.278 , for the annual average flow was 0.206 , and for the annual flood peak discharge was 0.069 , all indicating an absence of significant trends in spite of precipitation having a significant increasing trend with a p-value of 0.014 .

For the period 1969-2008 there were very few significant trends in streamflow characteristics and no significant trends in precipitation as shown in table 3. Stationarity of data (statistical properties of peak flows and watershed characteristics affecting flows that do not change with time) is an important criterion for conducting accurate frequency analyses.

Table 3. Selected streamflow-gaging stations in Wisconsin and corresponding Kendall tau and p-values of trends for annual 7-day low flow, annual average flow, annual flood peak discharge, and annual average precipitation for the 1969-2008 period with statistically significant values of $p$ less than 0.05 in bold and highlighted.

\begin{tabular}{|c|c|c|c|c|c|c|c|c|c|}
\hline \multirow{2}{*}{$\begin{array}{l}\text { USGS } \\
\text { station } \\
\text { number }\end{array}$} & \multirow[t]{2}{*}{ ream name and location } & \multicolumn{2}{|c|}{$\begin{array}{c}\text { Annual } \\
\text { 7-day low flow }\end{array}$} & \multicolumn{2}{|c|}{$\begin{array}{c}\text { Annual } \\
\text { average flow }\end{array}$} & \multicolumn{2}{|c|}{$\begin{array}{c}\text { Annual flood } \\
\text { peak discharge }\end{array}$} & \multicolumn{2}{|c|}{$\begin{array}{c}\text { Annual average } \\
\text { precipitation }\end{array}$} \\
\hline & & Tau & p-value & Tau & p-value & Tau & p-value & Tau & p-value \\
\hline \multicolumn{10}{|c|}{ Forested streams } \\
\hline 04071000 & Oconto River near Gillett & -0.2993 & 0.007 & -0.3019 & 0.006 & -0.2404 & 0.032 & -0.1258 & 0.258 \\
\hline 05333500 & St. Croix River near Danbury & -0.1809 & 0.124 & -0.1397 & 0.236 & -0.0225 & 0.855 & -0.0513 & 0.650 \\
\hline 04027000 & Bad River near Odanah & 0.0128 & 0.917 & -0.1552 & 0.162 & -0.0333 & 0.771 & -0.0769 & 0.492 \\
\hline 05394500 & Prairie River near Merrill & -0.1771 & 0.110 & -0.1844 & 0.098 & -0.0783 & 0.484 & -0.0795 & 0.477 \\
\hline & 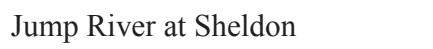 & -0.0950 & 0.395 & -0.1182 & 0.289 & 82 & 0.8 & -0.0846 & 0.449 \\
\hline \multicolumn{10}{|c|}{ Agricultural streams } \\
\hline 054 & Kickapoo $\mathrm{F}$ & 0.0889 & 0.428 & 0.0321 & 0.780 & -0.0090 & 0.944 & 1692 & 0.127 \\
\hline 05379500 & Trempealeau River at Dodge & 0.0758 & 0.499 & -0.0231 & 0.843 & -0.1130 & 0.311 & 0.0192 & 0.870 \\
\hline 05414000 & Platte River near Rockville & 0.0167 & 0.889 & -0.0900 & 0.421 & -0.2692 & 0.015 & 0.1963 & 0.077 \\
\hline 04073500 & Fox River at Berlin & -0.0218 & 0.852 & -0.0308 & 0.789 & -0.1373 & 0.217 & 0.0743 & 0.507 \\
\hline 05399500 & Big Eau Pleine River at Stratford & -0.0385 & 0.735 & -0.1734 & 0.118 & -0.1683 & 0.130 & -0.0846 & 0.449 \\
\hline 04087000 & Milwaukee River at Milwaukee & -0.1080 & 0.333 & -0.0128 & 0.917 & -0.1309 & 0.239 & 0.0974 & 0.382 \\
\hline 05436500 & Sugar River at Brodhead & 0.0901 & 0.421 & 0.1359 & 0.221 & 0.0436 & 0.701 & 0.2065 & 0.062 \\
\hline 05545750 & Fox River near New Munster & -0.0583 & 0.615 & 0.0285 & 0.811 & 0.0667 & 0.552 & 0.1410 & 0.204 \\
\hline 05426000 & Crawfish River at Milford & 0.1769 & 0.110 & 0.0897 & 0.421 & -0.0577 & 0.608 & 0.2077 & 0.061 \\
\hline 05430500 & Rock River at Afton & 0.1244 & 0.263 & 0.1040 & 0.351 & 0.0282 & 0.807 & 0.2051 & 0.064 \\
\hline
\end{tabular}


The 1969-2008 period was selected as a good period to represent flow characteristics for this study and future lowflow studies for the following reasons:

1. Graphical analysis of annual flow characteristics showed little (if any) trend for all 15 streamflow-gaging stations.

2. Kendall tau-trend tests found very few statistically significant trends in streamflow characteristics and no statistically significant trend in precipitation.

3. Potter (1991) and Trimble (1981) reported that most of the agricultural practices and land-use changes had occurred by the late 1960s.

4. Selecting a period with no apparent trends provides estimates that best represent current flow conditions in order to provide a more accurate estimate of low-flow characteristics at sewage-treatment and industrial plants for compliance with Wisconsin water-quality standards.

\section{Comparison of Annual Flow Characteristics}

Changes in streamflow characteristics and precipitation were determined between the 1915-68 and the 1969-2008 periods. Statistically significant changes for all three streamflow characteristics occurred at many streamflow-gaging stations with the most significant occurring in the agricultural areas. The percent change between the two periods for annual 7-day low flow, annual average flow, annual flood peak discharge and annual average precipitation is shown in figure 5. A summary of the percent differences between the forested and agricultural watersheds is shown in table 4. As shown, the percent increase in annual 7-day low flow, annual average flow and annual average precipitation is much larger in agricultural watersheds compared to forested watersheds. The decrease in annual flood peak discharge is also larger in the agricultural watersheds. Graphs showing percent change in annual streamflow characteristics and annual precipitation between the 1915-68 and 1969-2008 periods with significant differences (p-value less than 0.05 ) indicated by an asterisk.
The percent change in annual 7-day low flow and annual flood peak discharge related to forested area had a similar relationship pattern as found in the previous study by Gebert and Krug (1996). In that study, predominantly agricultural streams had increased low flow and decreased flood peak discharge while heavily forested areas had little change in low flow or flood peak discharge. Figure 6 shows a similar pattern of changes in low flow values with increasing percent forest cover..

\section{Streamflow Frequency Characteristics}

Streamflow frequency characteristics are often used for design purposes and compliance purposes such as bridge, culvert and wastewater treatment sizing and effluent limits. To determine changes in streamflow frequency characteristics, Log Pearson analysis was done for the 15 streamflow-gaging stations for each of the three flow characteristics. The streamflow frequency characteristics were computed for the periods 1915-2008, 1915-68, and 1969-2008 or as close to those periods as possible because some stations did not have data back to 1915 . The streamflow records were extended for the full time periods for low flow and average flow characteristics but not for flood peak discharge characteristics as described in "Data Analysis."

For example, a comparison of the streamflow frequency characteristics at four streamflow-gaging stations for the periods is shown in table 5. The stations were chosen to illustrate the changes in different parts of the State and between forested and agricultural areas.

The St. Croix and Oconto Rivers, both heavily forested basins, showed little change between the two periods in low-flow characteristics and annual average flow. The 100year flood peak discharges $\left(\mathrm{P}_{100}\right)$ decreased significantly for both streams. The Oconto River had a decrease of 33 percent and the St. Croix had a decrease of 12 percent between the 1969-2008 period and 1915-68 period.

Table 4. Summary of percent changes from 1915-68 to 1969-2008 in annual streamflow characteristics and annual precipitation in 14 watersheds.

\begin{tabular}{lcccc}
\hline \multicolumn{1}{c}{ Watershed } & $\begin{array}{c}\text { Average annual } \\
\text { 7-day low flow }\end{array}$ & $\begin{array}{c}\text { Average annual } \\
\text { flow }\end{array}$ & $\begin{array}{c}\text { Average annual flood } \\
\text { peak discharge }\end{array}$ & $\begin{array}{c}\text { Average annual } \\
\text { precipitation }\end{array}$ \\
\hline Average for five forested watersheds & 15 & 0.6 & -8.4 & 3.3 \\
Average for nine agricultural watersheds* & 60 & 23 & -15 & 8.2 \\
Average for all 14 watersheds* & 45 & 16 & -12 & 6.6 \\
\hline
\end{tabular}

"Note Rock River at Afton data not included in averages since the Crawfish River is in the Rock River at Afton drainage area. 
Percent change in average annual 7-day low flow

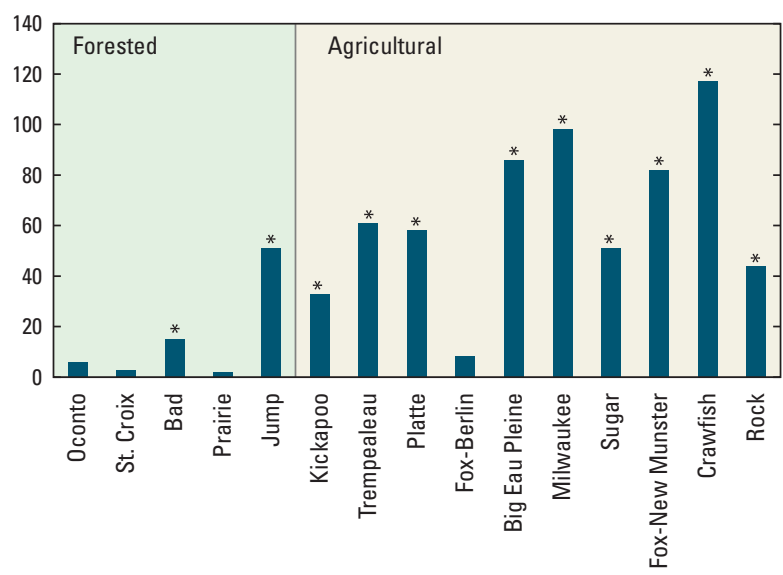

River

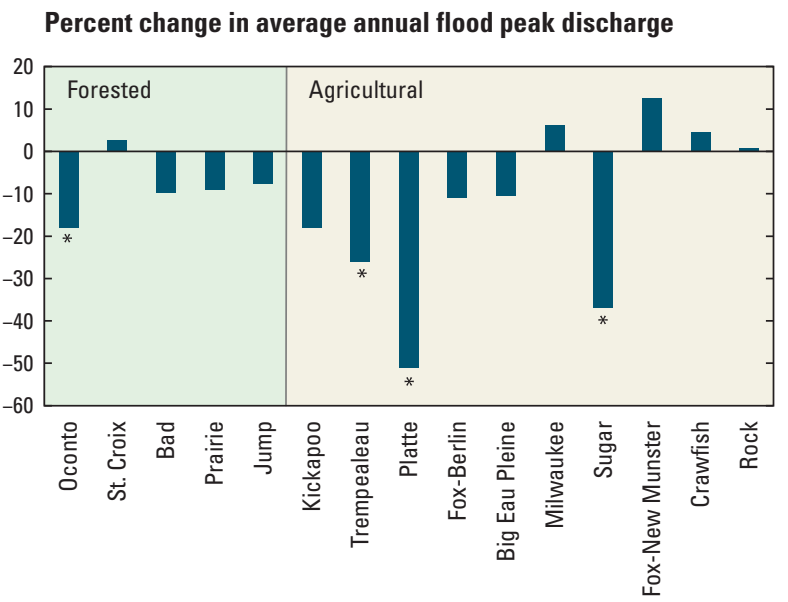

River

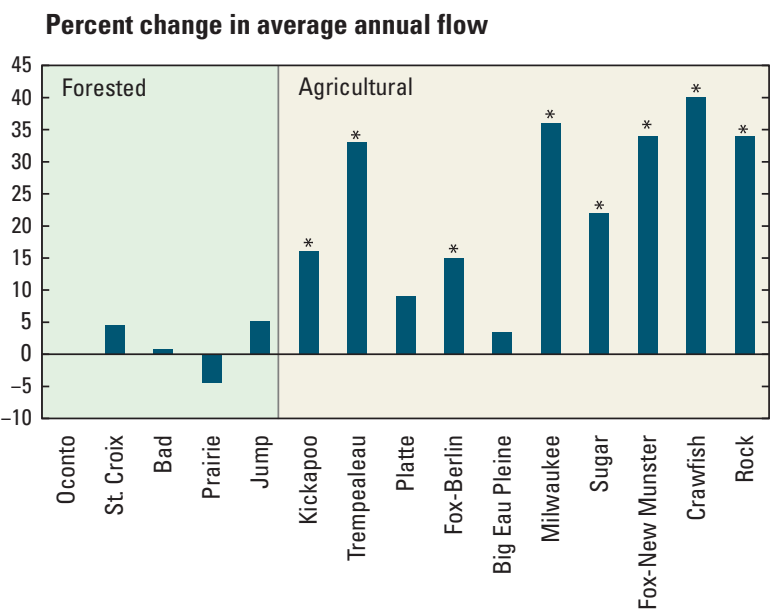

River
Percent change in average annual precipitation

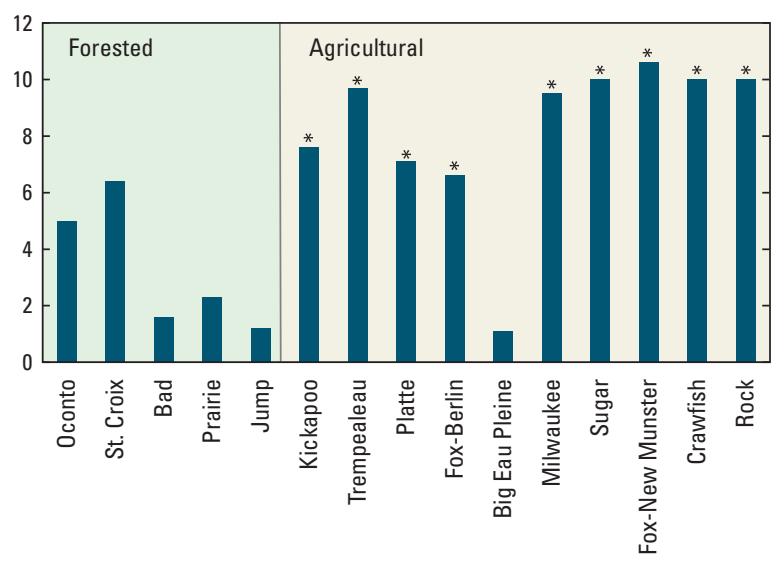

River

Figure 5. Percent change in annual streamflow characteristics and annual precipitation between the 1915-68 and 1969-2008 periods with significant differences ( $p$-values less than 0.05 ) indicated by an asterisk. 


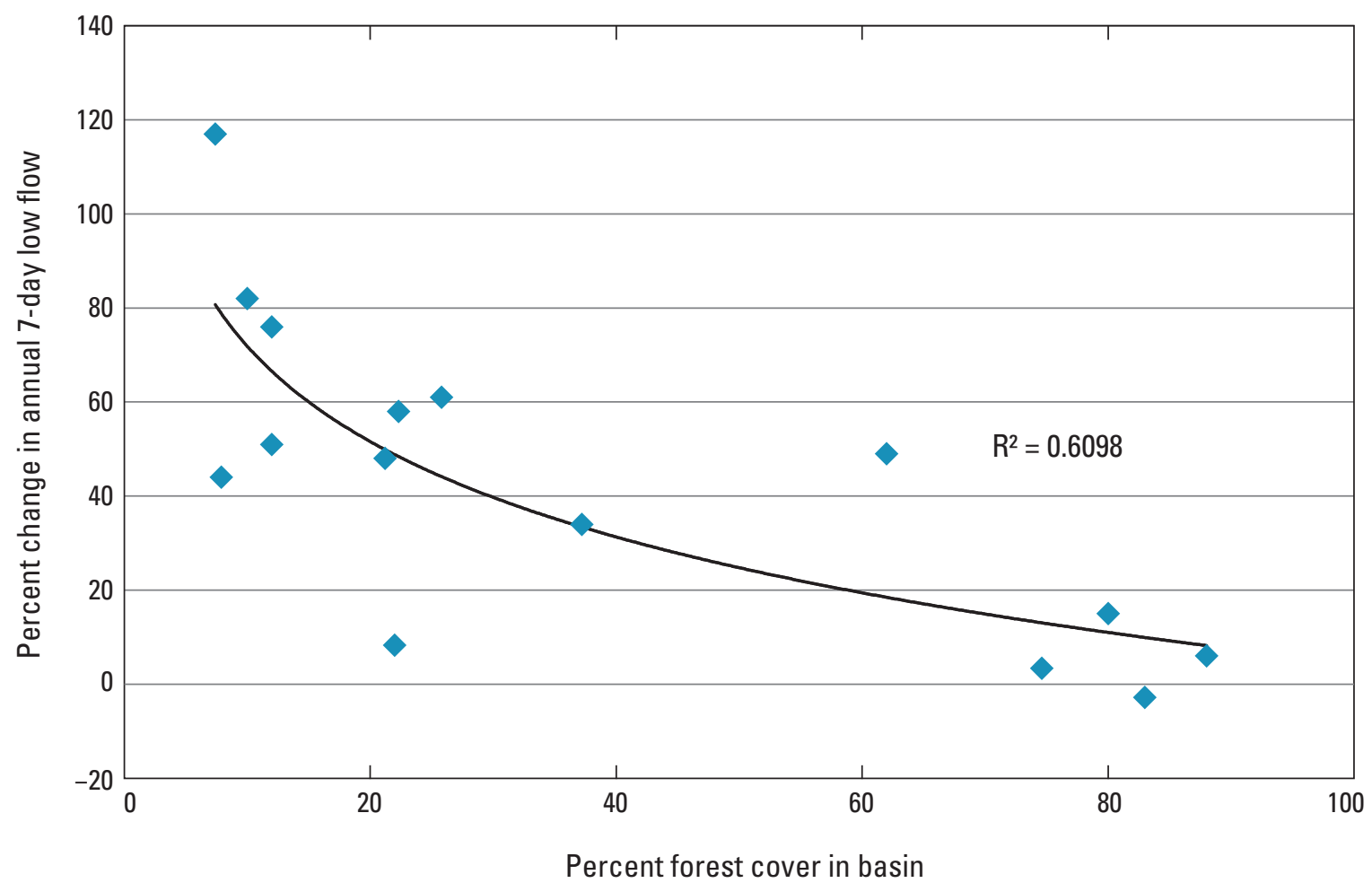

Figure 6. Changes in annual 7-day low flow from 1915-68 to 1969-2008 related to forest cover in Wisconsin. 
Table 5. Comparison of streamflow frequency characteristics for various periods at four streamflow-gaging stations in Wisconsin. Land cover percentages determined by 2002 National Land Cover Dataset.

$\left[\mathrm{Q}_{7,2}\right.$, annual minimum 7-day mean flow below which the low flow falls on average of once in 2 years; $\mathrm{ft}^{3} / \mathrm{s}$, cubic foot per second; $\mathrm{Q}_{7,10}$, annual minimum 7-day mean flow which the flow falls on average of once in 10 years; $\mathrm{P}_{2}$, annual flood peak discharge that will be exceeded on average of once in 2 years; $\mathrm{P}_{100}$, annual flood peak discharge that will be exceeded on average of once in 100 years; Qavg, mean of the daily flows over the period of record; Baseflow, average annual base flow over the period of record; Precipitation, average annual precipitation over the period of record; in., inches]

\begin{tabular}{|c|c|c|c|c|c|c|}
\hline \multirow{2}{*}{$\begin{array}{l}\text { Streamflow } \\
\text { characteristics }\end{array}$} & \multicolumn{3}{|c|}{$\begin{array}{l}\text { Streamflow in cubic feet per second } \\
\text { for indicated period of data }\end{array}$} & \multirow{2}{*}{$\begin{array}{c}\text { Percent change } \\
\text { from } 1915-68 \text { to } \\
1969-2008\end{array}$} & \multirow{2}{*}{$\begin{array}{l}\text { Forested lands } \\
\text { (percent) }\end{array}$} & \multirow{2}{*}{$\begin{array}{l}\text { Agricultural } \\
\text { lands (percent) }\end{array}$} \\
\hline & 1915-2008 & $1915-68$ & 1969-2008 & & & \\
\hline \multicolumn{5}{|c|}{ St. Croix River near Danbury } & 76 & 9 \\
\hline $\mathrm{Q}_{7,2}\left(\mathrm{ft}^{3} / \mathrm{s}\right)$ & 720 & 707 & 735 & 3.9 & & \\
\hline $\mathrm{Q}_{7,10}\left(\mathrm{ft}^{3} / \mathrm{s}\right)$ & 539 & 531 & 541 & 1.8 & & \\
\hline $\mathrm{P}_{2}\left(\mathrm{ft}^{3} / \mathrm{s}\right)$ & 4,740 & 4,610 & 4,920 & 6.7 & & \\
\hline $\mathrm{P}_{100}\left(\mathrm{ft}^{3} / \mathrm{s}\right)$ & 11,300 & 12,200 & 10,700 & -12.3 & & \\
\hline Qavg $\left(\mathrm{ft}^{3} / \mathrm{s}\right)$ & 1,310 & 1,290 & 1,350 & 4.6 & & \\
\hline Base flow $\left(\mathrm{ft}^{3} / \mathrm{s}\right)$ & 1,050 & 1,040 & 1,070 & 3.7 & & \\
\hline Precipitation (in.) & 31 & 29.8 & 31.7 & 6.4 & & \\
\hline \multicolumn{5}{|c|}{ Oconto River near Gillett } & 80 & 11 \\
\hline $\mathrm{Q}_{7,2}\left(\mathrm{ft}^{3} / \mathrm{s}\right)$ & 248 & 238 & 261 & 9.7 & & \\
\hline $\mathrm{Q}_{7,10}\left(\mathrm{ft}^{3} / \mathrm{s}\right)$ & 185 & 181 & 190 & 4.5 & & \\
\hline $\mathrm{P}_{2}\left(\mathrm{ft}^{3} / \mathrm{s}\right)$ & 2,380 & 2,560 & 2,170 & -15.0 & & \\
\hline $\mathrm{P}_{100}\left(\mathrm{ft}^{3} / \mathrm{s}\right)$ & 6,250 & 7,250 & 4,880 & -33.0 & & \\
\hline Qavg $\left(\mathrm{ft}^{3} / \mathrm{s}\right)$ & 565 & 567 & 565 & 0.0 & & \\
\hline Base flow ( $\left.\mathrm{ft}^{3} / \mathrm{s}\right)$ & 424 & 413 & 445 & 7.7 & & \\
\hline Precipitation (in.) & 30.3 & 29.8 & 31.2 & 4.7 & & \\
\hline \multicolumn{5}{|c|}{ Milwaukee River at Milwaukee } & 26 & 53 \\
\hline $\mathrm{Q}_{7,2}\left(\mathrm{ft}^{3} / \mathrm{s}\right)$ & 70.8 & 52.0 & 102 & 96.0 & & \\
\hline $\mathrm{Q}_{7,10}\left(\mathrm{ft}^{3} / \mathrm{s}\right)$ & 29.5 & 23.2 & 62.2 & 168.0 & & \\
\hline $\mathrm{P}_{2}\left(\mathrm{ft}^{3} / \mathrm{s}\right)$ & 4,650 & 4540 & 4840 & 6.6 & & \\
\hline$P_{100}\left(\mathrm{ft}^{3} / \mathrm{s}\right)$ & 15,300 & 15,000 & 15,600 & 4.0 & & \\
\hline Qavg $\left(\mathrm{ft}^{3} / \mathrm{s}\right)$ & 442 & 382 & 525 & 37.0 & & \\
\hline Base flow $\left(\mathrm{ft}^{3} / \mathrm{s}\right)$ & 211 & 163 & 277 & 70.0 & & \\
\hline Precipitation (in.) & 31.1 & 29.9 & 32.8 & 9.7 & & \\
\hline \multicolumn{5}{|c|}{ Sugar River at Brodhead } & 15 & 76 \\
\hline $\mathrm{Q}_{7,2}\left(\mathrm{ft}^{3} / \mathrm{s}\right)$ & 154 & 128 & 200 & 56.0 & & \\
\hline $\mathrm{Q}_{7,10}\left(\mathrm{ft}^{3} / \mathrm{s}\right)$ & 101 & 92.4 & 141 & 53.0 & & \\
\hline$P_{2}\left(f^{3} / s\right)$ & 3,130 & 3,730 & 2,550 & -32.0 & & \\
\hline$P_{100}\left(\mathrm{ft}^{3} / \mathrm{s}\right)$ & 14,600 & 16,800 & 9,880 & -41.0 & & \\
\hline Qavg $\left(\mathrm{ft}^{3} / \mathrm{s}\right)$ & 366 & 334 & 409 & 22.0 & & \\
\hline Base flow $\left(\mathrm{ft}^{3} / \mathrm{s}\right)$ & 237 & 197 & 291 & 48.0 & & \\
\hline Precipitation (in.) & 32.6 & 31.3 & 34.4 & 9.9 & & \\
\hline
\end{tabular}


The two streams with agriculture as the dominant land use (Milwaukee and Sugar Rivers) had large increases in the 7-day, 2-year low flow $\left(\mathrm{Q}_{7,2}\right)$ and 7-day, 10-year low flow $\left(Q_{7,10}\right)$. The average increase for the two sites was 76 percent for $\mathrm{Q}_{7,2}$ and 111 percent for $\mathrm{Q}_{7,10}$. The annual average flow $\left(\mathrm{Q}_{\mathrm{avg}}\right)$ increased an average of 30 percent. The changes in flood peak discharge for the two streams were mixed. The Milwaukee River had only a slight increase in both the 2-year $\left(\mathrm{P}_{2}\right)$ and 100-year $\left(\mathrm{P}_{100}\right)$ flood peak discharges. The Sugar River had a decrease of 32 percent for the 2-year $\left(\mathrm{P}_{2}\right)$ and a decrease of 41 percent for the 100-year $\left(\mathrm{P}_{100}\right)$ flood peak discharge.

Figure 7 is a comparison of the changes in low flow and flood peak discharge frequency characteristics for all 15 streamflow-gaging stations. A table showing the comparison of all three streamflow characteristics for all 15 streamflowgaging stations and averages for the forested and agricultural watersheds is shown in Appendix1; the average annual precipitation for each gaging station is also shown in the Appendix 1.

When the changes between 1915-68 and 1969-2008 are compared, the $\mathrm{Q}_{7,2}$ discharge increased 66 percent and the $\mathrm{Q}_{7,10}$ discharge increased 91 percent at the nine agricultural streamflow-gaging stations. Nine streamflow gaging stations were used instead of 10 to avoid double counting the Crawfish River and Rock River at Afton since they are in the same watershed. For the five forested streamflow-gaging stations, both the $\mathrm{Q}_{7,2}$ and the $\mathrm{Q}_{7,10}$ increased 18 percent. An overall decrease in flood-frequency values occurred between the two periods for both land-use types. For the nine agricultural streamflow-gaging stations, the 2-year flood peak discharge decreased an average of 13 percent, and the 100-year flood peak discharge decreased an average of 15 percent. For the five forested streamflow-gaging stations, the 2-year flood peak discharge decreased an average of 13 percent, and the 100year flood peak discharge decreased an average of 27 percent.

A comparison was made with low-flow characteristics that were previously computed for the Wisconsin River basins in the 1970s and 1980s for the design of sewage-treatment plants and industrial outfalls (Gebert and Holmstrom, 1977; Gebert, 1978, 1979a, 1979b, 1980, 1982; Holmstrom, 1978, 1979a, 1979b, 1980a, 1980b, 1982; Stedfast, 1979). Most of the streamflow data used in those reports were for the entire period of data at a streamflow-gaging station through the mid-1970s depending upon when the report was prepared; therefore, the low-flow characteristics in table 3 for the 1915-68 period are fairly representative of those published in these low-flow reports. A comparison of the $\mathrm{Q}_{7,10}$ discharges between the report values (Holmstrom, 1980a, 1980b, 1982; Stedfast, 1979) and the values for the 1915-68 period showed the average difference is less than 5 percent.

The $Q_{7,10}$ is the frequency characteristic used in wasteload allocation studies to design sewage-treatment plants and to permit industrial-outfall discharges. For streamflow-gaging stations where the dominant land use is agricultural, significant increases have occurred. The $\mathrm{Q}_{7,10}$ has increased from previously published values in the 1970s and 1980s from 0 percent for the Fox River at Berlin to 278 percent for the Crawfish River. This increase is very important because these 10 streamflow-gaging stations were some of the index stations used to make estimates of low-flow characteristics for 397 sewage-treatment plants and 143 industrial plants by Holmstrom (1979b).

The 100-year flood peak discharge is used in the design of bridges and in flood-plain mapping. The decrease in flood peak discharges could be significant for future design and mapping. The flood peak discharge values shown in figure 7 were calculated from Log-Pearson Type III analysis (U.S. Interagency Advisory Committee on Water Data, 1982). As shown in figure 7, the 100-year flood peak discharges decreased between the 1915-68 and 1969-2008 periods for 12 of the 15 streamflow-gaging stations. The decrease ranged from 1.0 percent for the Rock River at Afton to 43 percent for the Platte River at Rockville with an average decrease of 19 percent for the 15 stations. The largest increase was 9 percent for the Kickapoo River at Steuben. It should be noted that while low-flow characteristics have not been updated in a USGS report since the 1970s and 1980s, the peak discharges determined by Conger (1981) were updated periodically in subsequent reports by Krug and others (1992) and Walker and Krug (2003). 


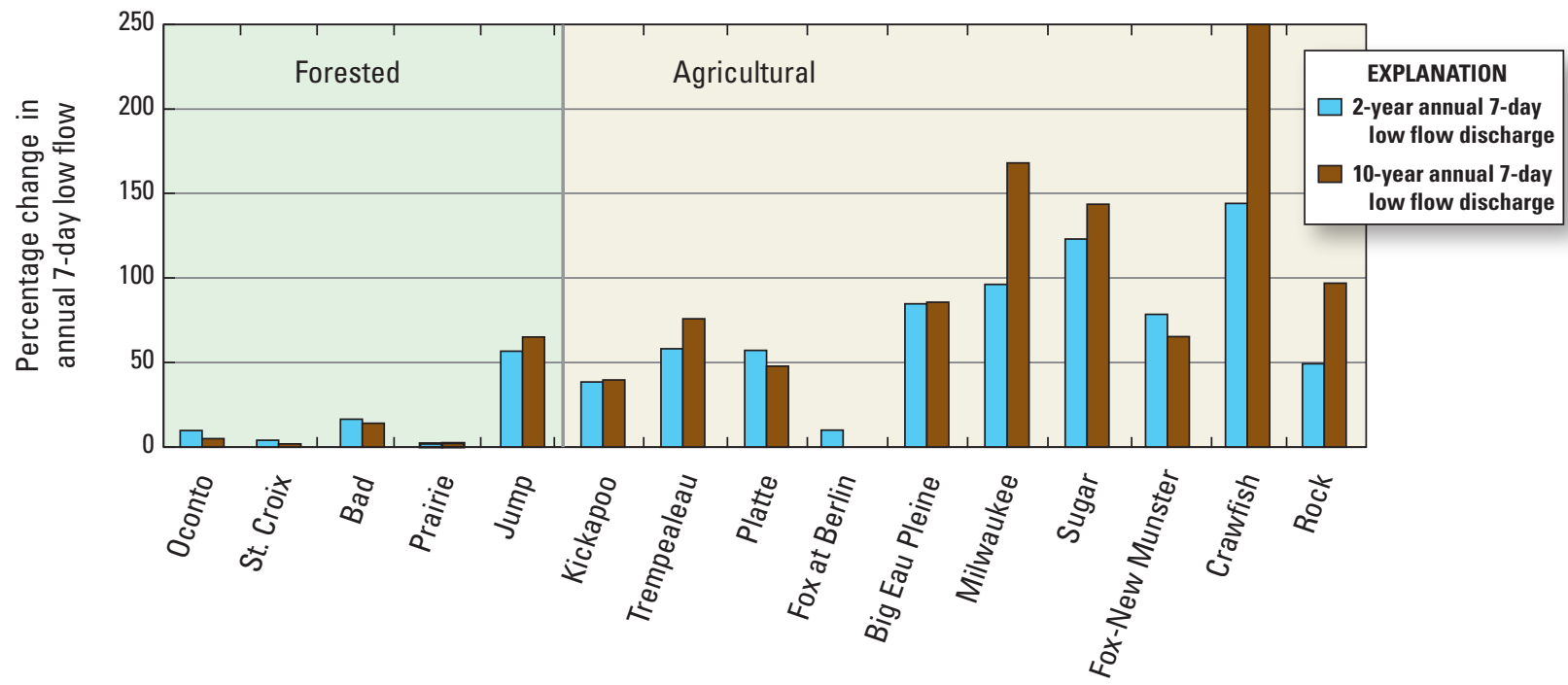

Streamflow-gaging station

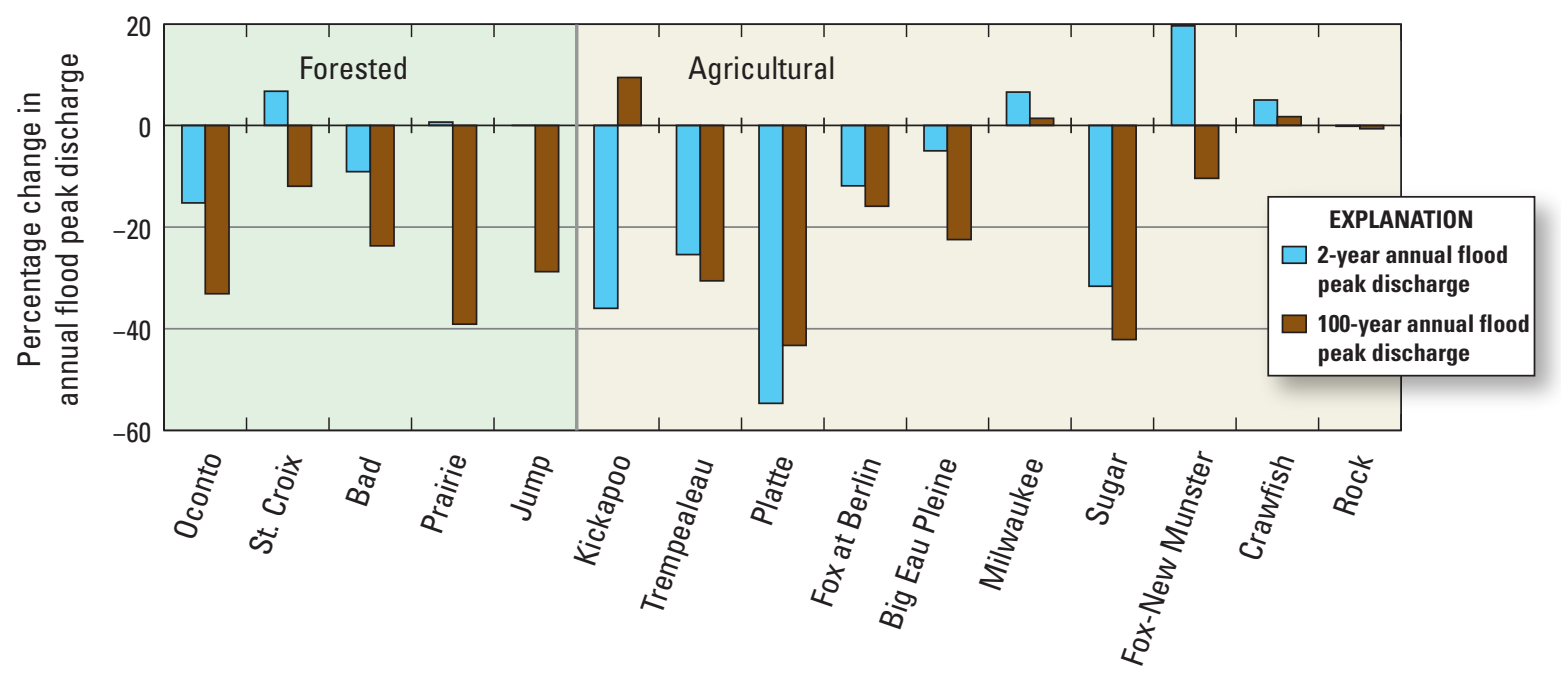

Streamflow-gaging station

Figure 7. Comparison of changes in streamflow frequency characteristics in Wisconsin rivers between the 1915-68 and 1969-2008 periods. 


\section{Annual Precipitation}

Table 6 lists the average annual precipitation for the 15 streamflow-gaging station watersheds for the periods 1915-68 and 1969-2008 along with percent change between the 2 periods. The average annual precipitation increased at all watersheds for the period 1969-2008 when compared with 1915-68. The changes were statistically significant at 8 of the 15 watersheds. The largest increase was 10.6 percent for the Fox River at New Munster. The smallest increase was 1.1 percent in the Big Eau Pleine watershed. The average increase for all 15 streamflow stations was 6.6 percent.

Figure 8 shows the average monthly change for the nine climatic divisions. The largest increases occurred in MarchApril, July-August, and October-December. The monthly increases ranged from about 7 to 19 percent for these months.
The only months that had decreases were February and June. Many of the months that had the largest increases (March, April, October, November, and December) are when groundwater recharge is likely to occur due to reduced evapotranspiration. The potential increase in groundwater recharge is likely part of the reason that low flows have increased.

The relation between changes in the average annual precipitation with changes in annual 7-day low flow, average annual flow, and annual flood peak discharge for each of the 15 streamflow-gaging stations is shown in figure 9 . A strong relation $\left(\mathrm{R}^{2}=0.84\right)$ was found between increased annual precipitation and increased average annual flow. A fair relation also was found between increased annual precipitation and increased annual 7-day low flow $\left(\mathrm{R}^{2}=0.46\right)$, while no apparent relation was found between increased annual precipitation and the changes in annual flood peak discharge.

Table 6. Average annual precipitation, in inches, for streamflow-gaging station watersheds in Wisconsin for the periods 1915-68 and 1969-2008 and percent increase between periods, with statistically significant values in bold and highlighted.

\begin{tabular}{|c|c|c|c|c|}
\hline & \multirow{2}{*}{ Climatic divisions } & \multicolumn{3}{|c|}{ Average annual precipitation } \\
\hline & & $1915-68$ & 1969-2008 & Percent increase \\
\hline \multicolumn{5}{|c|}{ Forested streams } \\
\hline Oconto River & 3 & 29.8 & 31.3 & 5.0 \\
\hline St. Croix River & 1 & 29.8 & 31.7 & 6.4 \\
\hline Bad River & 1,2 & 31.6 & 32.1 & 1.6 \\
\hline Prairie River & 2,3 & 31.1 & 31.8 & 2.3 \\
\hline Jump River & 1,2 & 31.7 & 32.1 & 1.2 \\
\hline \multicolumn{4}{|c|}{ Average for five forested streams } & 3.3 \\
\hline \multicolumn{5}{|c|}{ Agricultural streams } \\
\hline Kickapoo River & 4,7 & 31.7 & 34.1 & 7.6 \\
\hline Trempealeau River & 4 & 30.3 & 33.2 & 9.7 \\
\hline Platte River & 7 & 32.1 & 34.4 & 7.1 \\
\hline Fox River at Berlin & $5,6,8$ & 30.7 & 32.8 & 6.6 \\
\hline Big Eau Pleine River & 2 & 31.8 & 32.1 & 1.1 \\
\hline Milwaukee River & $6,8,9$ & 29.9 & 32.8 & 9.5 \\
\hline Sugar River & 8 & 31.3 & 34.4 & 10.0 \\
\hline Fox River near New Munster & 9 & 30.8 & 34.0 & 10.6 \\
\hline Crawfish River & $5,6,8$ & 31.3 & 34.4 & 10.0 \\
\hline Rock River & $5,6,8,9$ & 30.9 & 34.1 & 10.1 \\
\hline \multicolumn{4}{|c|}{ Average for 10 agricultural streams } & 8.2 \\
\hline \multicolumn{4}{|c|}{ Average for 15 streams } & 6.6 \\
\hline
\end{tabular}




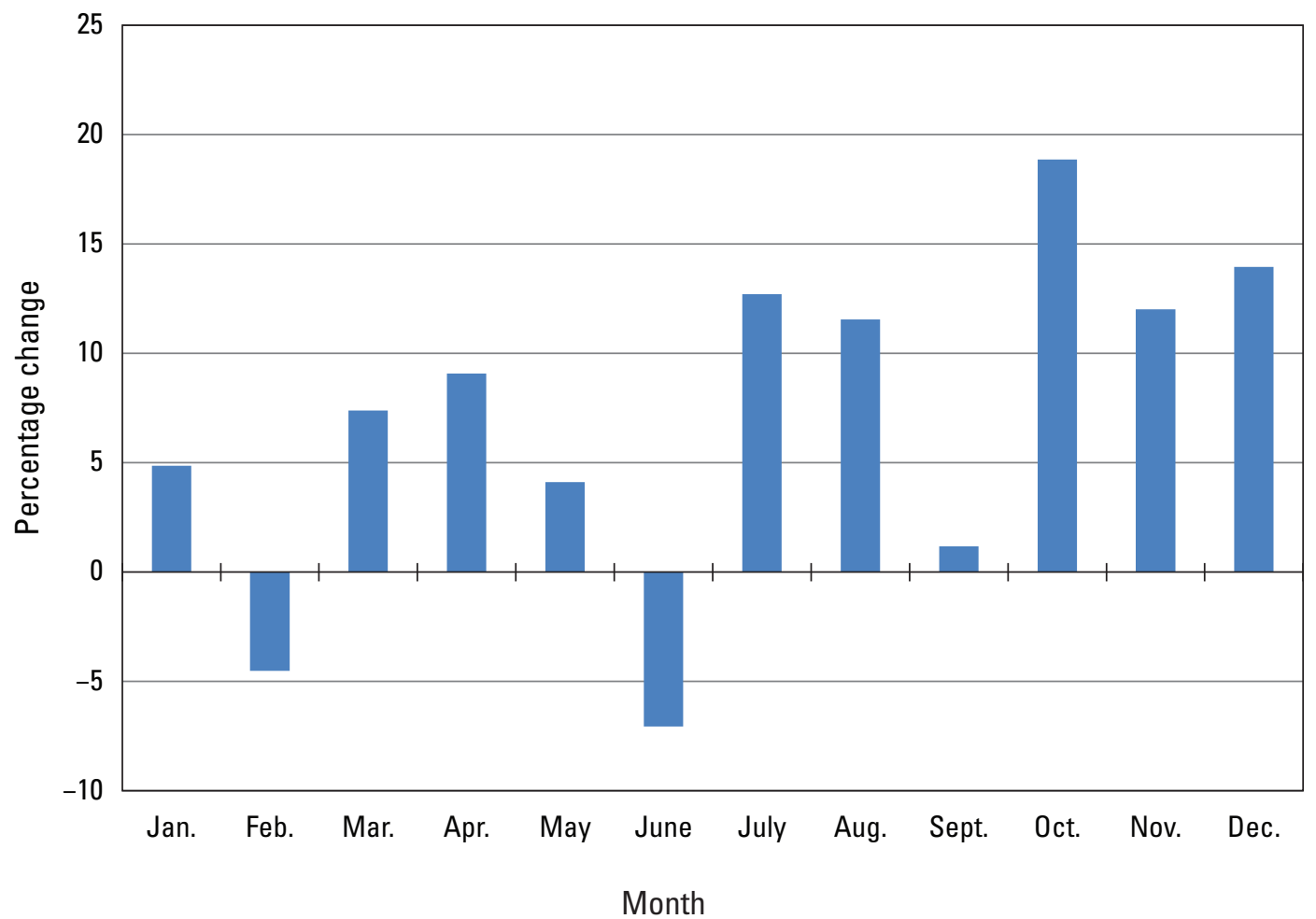

Figure 8. Average percent change in monthly precipitation for nine National Weather Service Climatic Divisions in Wisconsin from 1915-68 to 1969-2008. 

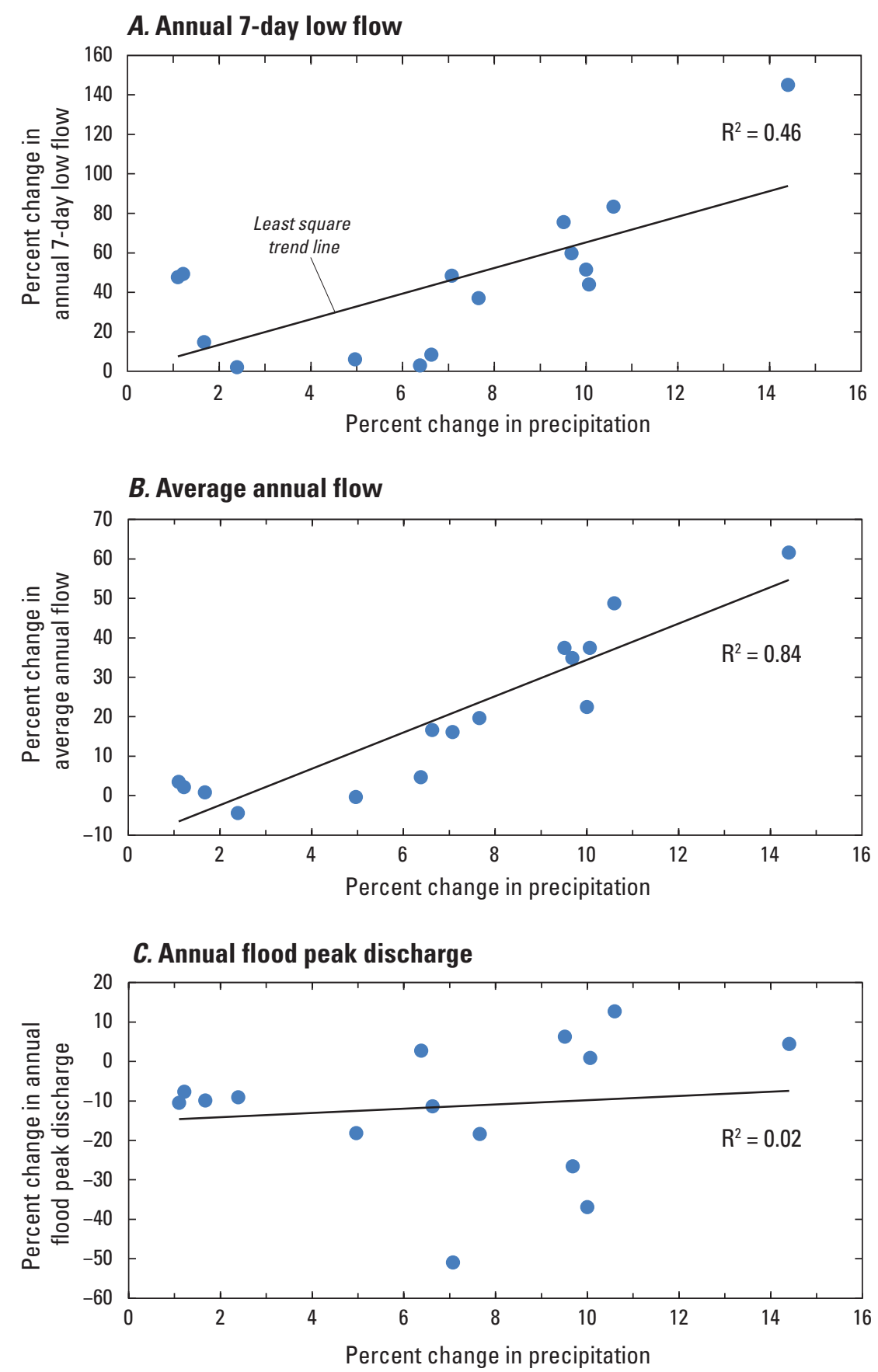

Figure 9. Percentage changes in $A$, annual 7-day low flow; $B$, average annual flow; and $C$, annual flood peak discharge in relation to percentage change in annual precipitation from 1915-68 to 1969-2008 in Wisconsin. 


\section{Discussion}

The significant trends in low flow that were found at 10 of the 15 streamflow-gaging stations appear to be the result of changes in agricultural practices and land use. An increase in annual precipitation also likely contributed to the increase in low flow and average annual flow. However, the increase in flow characteristics was much greater than the percent change in precipitation. The changes in annual flood peak discharge are not as consistent as for low flow and average annual flow. Annual flood peak discharge decreased at 12 streamflow-gaging stations and increased at 3 streamflowgaging stations. Five of the decreases in flood peak discharges were statistically significant as shown in table 2 . With an increase in annual precipitation and frequency of large rainfall events (Nelson Institute for Environmental Studies, 2011), an increase in annual flood peak discharge for most stations would be expected. However, a recent analysis of historical precipitation-frequency data for the 1-day and 1-hour duration reported no statistically significant trends in the data for the Midwest in general, although a few sites in southeastern Wisconsin had positive trends (Sanja and others, 2013). The decrease in annual flood peak discharges for a number of agricultural streams indicates that the changes in agricultural practices and land use may have resulted in increased infiltration, which was effective in decreasing annual peaks in spite of increased precipitation. This conclusion is similar to results reported by Juckem and others (2008). Comparing agricultural, forested and urban basins, Gyawali and others (2015) found streamflow characteristics changed least in forested basins. Their study evaluated changes in streamflow duration values at 13 streamflow-gaging stations in Wisconsin. They found the net change in total runoff between the 1951-80 and 1981-2010 periods for the northern basins ranged from -6.0 to 4.2 percent while the southern basins showed increases ranging from 13.1 to 18.2 percent.

The decrease in flood peak discharges in both forested and agricultural watersheds could also be caused by a shift in the timing of spring snowmelt runoff. Earlier snowmelt runoff by 5 to 10 days in the Great Lakes Basin from 1953 to 2002 was noted by Hodgkins and others (2007). This was the result of increased air temperatures in February and March of $5.0^{\circ} \mathrm{F}$ and $3^{\circ} \mathrm{F}$ respectively, from 1954 to 2004 . The earlier warming appears to extend the length of the snowmelt period and reduced the build-up of the snowpack in March resulting in lower flood peaks.
The difference in the average reduction in the 100-year flood peak discharge between the forested streams $(-27$ percent) and the agricultural streams ( -15 percent) was affected by inclusion of a large flood in 2008 that affected five of the agricultural streamflow-gaging stations. In June 2008, a greater than 100-year flood occurred in a narrow band across south-central Wisconsin (Fitzpatrick and others, 2008). The inclusion of that single event in the flood-frequency analysis changed the estimate of the 100-year flood discharge for the Kickapoo River at Steuben, Milwaukee River at Milwaukee, Fox River near New Munster, Crawfish River at Milford, and Rock River at Afton. Without these five stations the average reduction in the 100-year flood peak discharge would have been -31 percent, which is similar to the -27 percent for the five forested streams.

To evaluate the 1969-2008 period chosen for this study, a comparison was made with the long-term record at Fox River at Berlin. Fox River at Berlin was selected because it has the longest continuous streamflow record in Wisconsin, operating from 1898 to the present. As shown in figure 10, there is little variation in the annual 7-day low flow and annual average flow for the period 1898 to 2008. The Fox River at Berlin watershed is 49 percent agricultural and 32 percent forested. The streamflow characteristics do not have the same pattern as other agriculture-dominated basins in that the annual 7-day low flow did not increase between the periods. A reason for this is that a large portion of the drainage area has highly permeable soils resulting in many of the tributary streams having very large base flows (Gebert and others, 2007, 2009, and 2011). The 2009 report found that base flow for the Fox River at Berlin is 85 percent of the total flow; therefore, the agricultural practices that were implemented could have little effect on the low-flow characteristics of the Fox River. Annual average precipitation increased 6.6 percent on the watershed between the 1915-68 and 1969-2008 periods. Thus differences seen between the 1969-2008 and the 1898-2008 periods are likely the result of climatic variations.

Hodgkins and Dudley (2006), and Hodgkins and others (2007), in their studies of historical changes in precipitation and streamflow in the U.S. Great Lakes Basin, found that annual runoff increased at 38 of 43 streamflow-gaging stations during the period 1955-2004. Precipitation also increased by 4.5 inches during that same time period. 


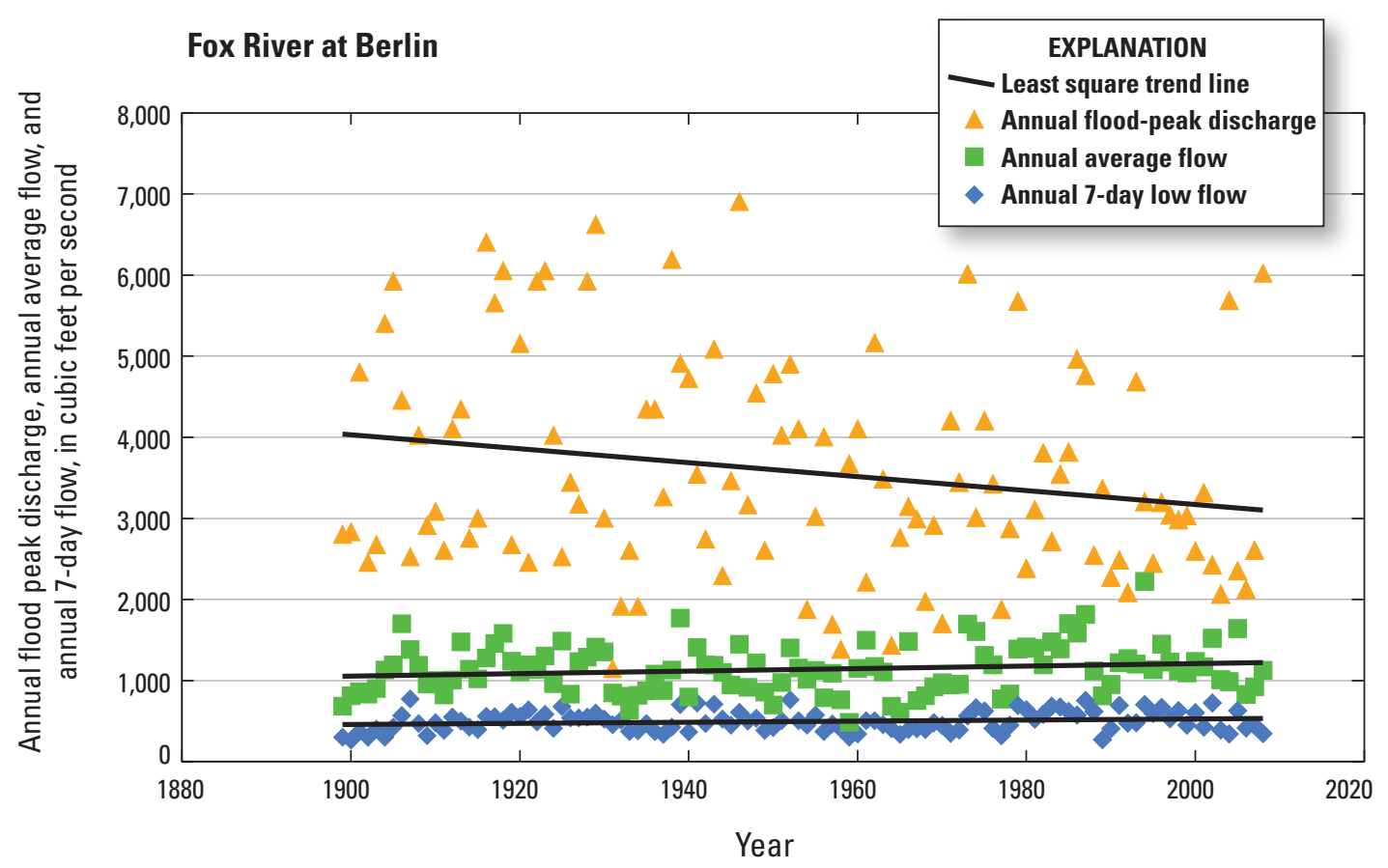

Figure 10. Annual streamflow characteristics for Fox River at Berlin, Wisconsin, for the period 1898-2008. 


\section{Summary and Conclusions}

Streamflow characteristics were determined for 15 streamflow-gaging stations in Wisconsin for 3 periods: 1915-2008, 1915-68, and 1969-2008. Trends in streamflow characteristics were found to be statistically significant at many stations. More trends in streamflow characteristics were found in basins where the predominant land use was agriculture as compared to basins where the predominant land use was forest. Annual precipitation changes also were determined for the same periods to help identify possible reasons for variations in streamflow for the different periods.

A statistically significant increasing trend for the annual 7-day low flow was found at 10 of the 15 streamflow-gaging stations using Kendall's tau test for the period of record from 1915-2008. Most of the increasing trends in annual 7-day low flow occurred in watersheds where the predominant land use was agriculture. Four of the five watersheds that had no trend for the 7-day low flow were in the forested northern part of the State. For the period 1969-2008, 14 of the 15 streamflowgaging stations had no significant trend for the annual 7-day low flow.

For annual average flow, 7 of the 15 streamflow-gaging stations had increasing trends for the period 1915-2008, all of which were in agricultural watersheds. Only one of the forested streamflow-gaging stations had a significant trend for the 1969-2008 period.

For annual flood peak discharge, 5 of the 15 streamflow-gaging stations had decreasing trends for the period 1915-2008; 4 of those 5 had agriculture as the predominant land use. Two of the streamflow-gaging stations (Oconto and Platte Rivers) had statistically significant decreasing trends for the period 1969-2008.

The annual 7-day low-flow characteristics increased for nine of the agricultural streamflow-gaging stations, having increased an average of 60 percent from the period 1915-68 to 1969-2008. The five forested streamflow-gaging stations increased an average of 15 percent and two stations had significant increases. There was a significant difference in annual average flow between the two periods in the two land-use categories: nine of the agricultural streams increased 23 percent, whereas the forested streams increased 0.6 percent, which was not found significant. Annual flood peak discharge for the agricultural streams decreased an average of 15 percent, and the forested streams decreased 8.4 percent.

Annual average precipitation in all 14 watersheds increased 6.6 percent for the 1969-2008 periods when compared with the 1915-68 period. Increased precipitation occurred in the nine climatic divisions in the state. The climatic divisions in the forested part of the State increased 3.3 percent as compared to climatic divisions in the southern agricultural part of the State that had an average increase of 8.2 percent. The largest increase of 10.6 percent was found in the southeastern part of the State.
The trends in streamflow characteristics affect frequency characteristics, which are used for a variety of design and compliance purposes. The discharges for specific frequencies for the 1969-2008 period were compared to frequencies for the 1915-68 period. The 7-day, 10-year $\left(\mathrm{Q}_{7,10}\right)$ low flow increased 91 percent for nine agricultural streams, while the five forested streams had an increase of 18 percent. The 100-year flood peak discharge decreased an average of 15 percent for streams in the agriculture area and 27 percent for streams in the forested area.

The 1969-2008 period was shown to represent current (2014) land use and climatic conditions, was generally free of trends, and is recommended for determining current streamflow characteristics for design and compliance purposes.

Increased annual precipitation, along with the changes in the months when precipitation increased, indicated climatic changes may be causing some of the changes in streamflow. These changes resulted in increased low flows and annual average flows. The changes in agricultural practices and land use had a dominant effect for increased low flows. Many flood peak discharges decreased, in spite of increased annual precipitation, likely due to increased infiltration resulting from changes in agricultural practices and changes in the seasonal distribution of precipitation.

\section{References Cited}

Conger, D.H., 1981, Techniques for estimating magnitude and frequency of floods for Wisconsin streams: U.S. Geological Survey Open-File Report 80-1214, 116 p.

Conover, W.J., 1971, Practical nonparametric statistics: New York, Wiley, $462 \mathrm{p}$.

Falcone, J.A, 2011, GAGES-II: Geospatial attributes of gages for evaluating streamflow [digital spatial dataset]: available at http://water.usgs.gov/GIS/metadata/usgswrd/XML/gagesII_Sept2011.xml.

Fitzpatrick, F.A., Peppler, M.C., Walker, J.F., Rose, W.J., Waschbusch, R.J., and Kennedy, J.L., 2008, Flood of June 2008, southern Wisconsin: U.S. Geological Survey Scientific Investigation Report 2008-5235, 24p.

Gebert, W.A., 1978, Low-flow characteristics of streams in the lower Wisconsin River basin: U.S. Geological Survey Water-Resources Investigations Report 77-118, 80 p.

Gebert, W.A., 1979a, Red Cedar River Basin, WisconsinLow-flow characteristics: U.S. Geological Survey WaterResources Investigations Report 79-29, 12 p.

Gebert, W.A., 1979b, Low-flow characteristics of streams in the Lake Superior Basin, Wisconsin: U.S. Geological Survey Water-Resources Investigations Report 79-38, 74 p. 
Gebert, W.A., 1980, Low-flow characteristics of streams in the upper Wisconsin River basin, Wisconsin: U.S. Geological Survey Open-File Report 80-691, 60 p.

Gebert, W.A., 1982, Low-flow characteristics of streams in the central Wisconsin River basin, Wisconsin: U.S. Geological Survey Open-File Report 81-495, 99 p.

Gebert, W.A., and Holmstrom, B.K., 1977, Low-flow characteristics at gaging stations on the Wisconsin, Fox, and Wolf Rivers, Wisconsin: U.S. Geological Survey WaterResources Investigations 77-27, 20 p.

Gebert, W.A., and Krug, W.R., 1996, Streamflow trends in Wisconsin's driftless area: Journal of the American Water Resources Association, v. 32, no. 4, p. 733-744.

Gebert, W.A., Radloff, M.J., Considine, E.J., and Kennedy, J.L., 2007, Use of streamflow data to estimate base flow/ ground-water recharge for Wisconsin: Journal of the American Water Resources Association, v. 43, no. 1, p. 220-236.

Gebert, W.A., Walker, J.F., and Hunt, R.J., 2009, Groundwater recharge in Wisconsin-Annual estimates for 1970-99 using streamflow data: U.S. Geological Survey Fact Sheet 2009-3092, 4 p., available at http://pubs.usgs.gov/ fs/2009/3092.

Gebert, W.A., Walker, J.F., and Kennedy, J.L., 2011, Estimating 1970-99 average annual groundwater recharge in Wisconsin using streamflow data: U.S. Geological Survey Open-File Report 2009-1210, 14 p. plus appendixes, available at http://pubs.er.usgs.gov/publication/ofr20091210.

Gyawali, Rabi, Greb, Steve, and Block, Paul, 2015, Temporal changes in streamflow and attribution of changes to climate and landuse in Wisconsin watersheds: Journal of the American Water Resources Association, v.51, no. 4, p. 1138-1152.

Hodgkins, G.A., and Dudley, R.W., 2006, Changes in timing of winter-spring streamflow in eastern North America, 1913-2002: Geophysical Research Letters, v.33, http://dx.doi.org/10.1029/2005GL025593.

Hodgkins, G.A., Dudley, R.W., and Aichele, S.S., 2007, Historical changes in precipitation and streamflow in the U.S. Great Lakes Basin, 1915-2004: U.S. Geological Survey Scientific Investigations Report 2007-5118, 31 p.

Holmstrom, B.K., 1978, Low-flow characteristics of streams in the Rock-Fox River Basin, Wisconsin: U.S. Geological Survey Water-Resources Investigations 78-85, 98 p.

Holmstrom, B.K., 1979a, Low-flow characteristics of streams in the Trempealeau-Black River Basin, Wisconsin: U.S. Geological Survey Water-Resources Investigations 79-9, $79 \mathrm{p}$.
Holmstrom, B.K., 1979b, Low-flow characteristics of Wisconsin streams at sewage-treatment plants and industrial plants: U.S. Geological Survey Water-Resources Investigations 79-31, $123 \mathrm{p}$.

Holmstrom, B.K., 1980a, Low-flow characteristics of streams in the St. Croix River Basin: U.S. Geological Survey Open-File Report 80-696, 62 p.

Holmstrom, B.K., 1980b, Low-flow characteristics of streams in the Menominee-Oconto-Peshtigo River Basin, Wisconsin: U.S. Geological Survey Open-File Report 80-749, 82 p.

Holmstrom, B.K., 1982, Low-flow characteristics of streams in the Lake Michigan Basin, Wisconsin: U.S. Geological Survey Open-File Report 81-1193, 102 p.

Juckem, P.F., R.J. Hunt, Anderson, M.P., and Robertson, D.M., 2008, Effects of climate and land management change on streamflow in the driftless area of Wisconsin: Journal of Hydrology, v. 355, nos. 1-4, p. 123-130.

Kendall, M.G., 1970, Rank correlation methods (4th ed.): London, Charles Griffin, 202 p.

Krug, W.R., 1996, Simulation of temporal changes in rainfallrunoff characteristics, Coon Creek Basin, Wisconsin: Journal of the American Water Resources Association, v. 32, no. 4 , p. $745-752$.

Krug, W.R., Conger, D.H., and Gebert, W.A., 1992, Flood-frequency characteristics of Wisconsin streams: U.S. Geological Survey Water-Resources Investigations Report 91-4128, 185 p.

Lins, H.F., 2012, USGS Hydro-Climatic Data Network 2009 (HCDN-2009): U.S. Geological Survey Fact Sheet 20123047, 4 p., available at http://pubs.usgs.gov/fs/2012/3047/.

McCabe, G.J. and Wolock, D.M., 2002, A step increase in streamflow in the conterminous United States: Geophysical Research Letters, v. 29, no. 24), p. 2185.

Nelson Institute for Environmental Studies, 2011, Wisconsin's changing climate-Impacts and adaptation: Madison, Wis., Wisconsin Initiative on Climate Change Impacts, University of Wisconsin-Madison and the Wisconsin Department of Natural Resources, http://www.wicci.wisc.edu/publications. php.

Potter, K.W., 1991, Hydrological impacts of changing land management practices in a moderate-sized agricultural catchment: Water Resources Research, v. 27, no. 5, p. $845-855$. 
Sanja, Perica, Martin, Deborah, Pavlovic, Sandra, Roy, Ishani, St. Laurent, Michael, Trypaluk, Carl, Unruh, Dale, Yekta, Michael, and Bonnin, Geoffrey, 2013, Precipitationfrequency atlas of the United States: NOAA Atlas 14, v. 8, ver. 2.0, National Oceanic and Atmospheric Administration, National Weather Service, Silver Spring, Maryland, accessed at http://www.nws.noaa.gov/oh/hdsc/PF_documents/Atlas14_Volume8.pdf.

Stedfast, D.A., 1979, Low-flow characteristics of streams in the Pecatonica-Sugar River Basin, Wisconsin: U.S. Geological Survey Open-File Report 79-1274, 92 p.

Trimble, S.W., 1981, Changes in sediment storage in the Coon Creek Basin, driftless area, Wisconsin, 1853 to 1975: Science, v. 214, no. 4517, p. 181-183.

Trimble, S.W., and Lund, S.W., 1982, Soil conservation and the reduction of erosion and sedimentation in the Coon Creek Basin, Wisconsin: U.S. Geological Survey Professional Paper 1234, 35 p.

U.S. Department of Commerce-National Oceanic and Atmospheric Administration, 2009, Climatic data-Wisconsin: Asheville, North Carolina., National Climatic Data Center accessed at http://www.ncdc.noaa.gov.
U.S. Geological Survey, 1976-2006, Water resources data, Wisconsin: U.S. Geological Survey Water-Data Reports (published annually).

U.S. Geological Survey, 2007-9, Water resources data, Wisconsin, water years 2006-8: U.S. Geological Survey Water-Data Report WDR-US-2007, available at: http:/wdr.water.usgs.gov/wy2007/search.jsp.

U.S. Interagency Advisory Committee on Water Data, 1982, Guidelines for determining flood-flow frequency, Bulletin 17-B of the Hydrology Subcommittee: Reston, Virginia, U.S. Geological Survey, Office of Water Data Coordination, [183 p.] (Available from the National Technical Information Service, Springfield Virginia 22161 as report no. PB 86157 278 or from the Federal Emergency Management Agency at http://www.fema.gov/mit/tsd/dl_flow.htm.

Walker, J.F., and Krug, W.R., 2003, Flood-frequency characteristics of Wisconsin streams: U.S. Geological Survey Water-Resources Investigations Report 03-4250, 37 p.

Wessa, Patrick, 2012, Kendall tau rank correlation (v. 1.0.11), in Free Statistics Software (v. 1.1.23-r7): Office for Research Development and Education, http://www.wessa. net/rwasp_kendall.wasp/. 
Appendix 1. Comparison of streamflow characteristics and precipitation between 1915-68 and 1969-2008.

$\left[\mathrm{mi}^{2}\right.$, square miles; $\mathrm{Q}_{7,2}$, annual minimum 7-day mean flow below which the low flow falls on average once in 2 years; $\mathrm{ft}^{3} / \mathrm{s}$, cubic foot per second; $\mathrm{Q}_{7,10}$, annual minimum 7-day mean flow which the flow falls on average once in 10 years; P2, annual flood peak discharge that will be exceeded on average once in 2 years; P100, annual flood peak discharge that will be exceeded on average once in 100 years; Qavg, mean of the daily flows over the period of record]

\begin{tabular}{|c|c|c|c|c|c|c|c|c|c|c|c|}
\hline \multirow{4}{*}{$\begin{array}{l}\text { USGS } \\
\text { station } \\
\text { number }\end{array}$} & \multirow{4}{*}{ Station name } & \multirow{4}{*}{$\begin{array}{l}\text { Drainage } \\
\text { area } \\
\text { mi }^{2}\end{array}$} & \multicolumn{6}{|c|}{ 7-Day low flow } & \multicolumn{3}{|c|}{ Average annual flow } \\
\hline & & & \multirow{2}{*}{\multicolumn{2}{|c|}{$1915-68$}} & \multirow{2}{*}{\multicolumn{2}{|c|}{ 1969-2008 }} & \multirow{2}{*}{\multicolumn{2}{|c|}{$\begin{array}{c}\text { Percent change } \\
1915-68 \text { to } \\
1969-2008\end{array}$}} & \multirow{3}{*}{$\begin{array}{c}1915-68 \\
\text { Oavg } \\
\left(\mathrm{ft}^{3} / \mathrm{s}\right)\end{array}$} & \multirow{3}{*}{$\begin{array}{c}1969-2008 \\
\begin{array}{c}\text { Qavg } \\
\left(\mathrm{ft}^{3} / \mathrm{s}\right)\end{array}\end{array}$} & \multirow{3}{*}{$\begin{array}{c}\text { Percent change } \\
\begin{array}{c}1915-68 \text { to } \\
1969-2008\end{array} \\
\text { Percent }\end{array}$} \\
\hline & & & & & & & & & & & \\
\hline & & & $\begin{array}{c}\mathbf{0}_{7,2} \\
\left(\mathrm{ft}^{3} / \mathbf{s}\right)\end{array}$ & $\begin{array}{c}\mathbf{0}_{7,10} \\
\left(\mathrm{ft}^{3} / \mathrm{s}\right)\end{array}$ & $\underset{\left(\mathbf{f t}^{3} / \mathbf{s}\right)}{\mathbf{0}_{\mathrm{i}}}$ & $\begin{array}{c}\mathbf{0}_{7,10} \\
\left(\mathrm{ft}^{3} / \mathrm{s}\right)\end{array}$ & $\frac{\mathbf{a}_{7,2}}{\text { (percent) }}$ & $\begin{array}{c}\mathbf{0}_{7,10} \\
\text { (percent) }\end{array}$ & & & \\
\hline \multicolumn{12}{|c|}{ Forested streams } \\
\hline 04071000 & $\begin{array}{l}\text { Oconto River near } \\
\text { Gillett }\end{array}$ & 678 & 238 & 181 & 261 & 190 & 10 & 5 & 567 & 565 & 0 \\
\hline 05333500 & $\begin{array}{l}\text { St. Croix River near } \\
\text { Danbury }\end{array}$ & 1,558 & 707 & 531 & 735 & 541 & 4 & 2 & 1,290 & 1,350 & 5 \\
\hline 04027000 & $\begin{array}{l}\text { Bad River near } \\
\text { Odanah }\end{array}$ & 597 & 93.6 & 60.2 & 109 & 68.7 & 16 & 14 & 605 & 610 & 1 \\
\hline 05394500 & $\begin{array}{l}\text { Prairie River near } \\
\text { Merrill }\end{array}$ & 184 & 71.5 & 60.0 & 73.0 & 61.3 & 2 & 2 & 181 & 173 & -4 \\
\hline 05362000 & $\begin{array}{l}\text { Jump River at } \\
\text { Sheldon }\end{array}$ & 574 & 33.3 & 18.9 & 52.2 & 31.2 & 57 & 65 & 510 & 521 & 2 \\
\hline Average fo & r five gaging stations & & & & & & 18 & 18 & 631 & 644 & 1 \\
\hline \multicolumn{12}{|c|}{ Agricultural streams } \\
\hline 05410490 & $\begin{array}{l}\text { Kickapoo River at } \\
\text { Steuben }\end{array}$ & 690 & 239 & 187 & 331 & 261 & 38 & 40 & 453 & 542 & 20 \\
\hline 05379500 & $\begin{array}{l}\text { Trempealeau River } \\
\text { at Dodge }\end{array}$ & 643 & 167 & 120 & 264 & 211 & 58 & 76 & 387 & 522 & 35 \\
\hline 05414000 & $\begin{array}{l}\text { Platte River near } \\
\text { Rockville }\end{array}$ & 142 & 31.8 & 21.3 & 50.0 & 31.5 & 57 & 48 & 93 & 108 & 16 \\
\hline 04073500 & Fox River at Berlin & 1,430 & 478 & 362 & 525 & 362 & 10 & 0 & 1,080 & 1,260 & 17 \\
\hline 05399500 & $\begin{array}{l}\text { Big Eau Pleine } \\
\quad \text { River near } \\
\text { Stratford }\end{array}$ & 224 & 2.6 & 0.70 & 4.8 & 1.3 & 85 & 86 & 170 & 176 & 4 \\
\hline 04087000 & $\begin{array}{l}\text { Milwaukee River at } \\
\text { Milwaukee }\end{array}$ & 696 & 52 & 23.2 & 102 & 62.2 & 96 & 168 & 382 & 525 & 37 \\
\hline 05436500 & $\begin{array}{l}\text { Sugar River at } \\
\text { Brodhead }\end{array}$ & 523 & 128 & 92.4 & 200 & 141 & 56 & 53 & 334 & 409 & 22 \\
\hline 05545750 & $\begin{array}{l}\text { Fox River near } \\
\text { New Munster }\end{array}$ & 868 & 97.6 & 57.4 & 160 & 95.7 & 64 & 67 & 500 & 669 & 33 \\
\hline 05426000 & $\begin{array}{l}\text { Crawfish River at } \\
\text { Milford }\end{array}$ & 762 & 30.0 & 9.1 & 73.2 & 34.4 & 144 & 278 & 331 & 535 & 62 \\
\hline 05430500 & Rock River at Afton & 6,363 & 394 & 190 & 588.0 & 374.0 & 49 & 97 & 1,700 & 2,340 & 38 \\
\hline \multicolumn{7}{|c|}{ Average for nine gaging stations* } & 66 & 91 & & & 29 \\
\hline \multicolumn{7}{|c|}{ Average for 14 gaging stations* } & 50 & 64 & & & 18 \\
\hline
\end{tabular}

${ }^{*}$ Note: Rock River at Afton not included in averages since Crawfish River is in the Rock River at Afton drainage area. 
Appendix 1. Comparison of Streamflow Characteristics and Precipitation between 1915-68 and 1969-2008.-Continued

$\left[\mathrm{mi}^{2}\right.$, square miles; $\mathrm{Q}_{7,2}$, annual minimum 7-day mean flow below which the low flow falls on average of once in 2 years; $\mathrm{ft}^{3} / \mathrm{s}$, cubic foot per second; $\mathrm{Q}_{7,10}$, annual minimum 7-day mean flow which the flow falls on average of once in 10 years; P2, annual flood peak discharge that will be exceeded on average of once in 2 years; P100, annual flood peak discharge that will be exceeded on average of once in 100 years; Qavg, mean of the daily flows over the period of record]

\begin{tabular}{|c|c|c|c|c|c|c|c|c|c|c|}
\hline \multirow{4}{*}{$\begin{array}{l}\text { USGS } \\
\text { station } \\
\text { number }\end{array}$} & \multirow{4}{*}{ Station name } & \multicolumn{6}{|c|}{ Flood peak discharge } & \multicolumn{3}{|c|}{ Average annual precipitation } \\
\hline & & \multirow{2}{*}{\multicolumn{2}{|c|}{$1915-68$}} & \multirow{2}{*}{\multicolumn{2}{|c|}{ 1969-2008 }} & \multirow{2}{*}{\multicolumn{2}{|c|}{$\begin{array}{c}\text { Percent change } \\
1915-68 \text { to } \\
1969-2008\end{array}$}} & \multirow{3}{*}{$\begin{array}{l}\text { 1915-68 } \\
\text { (inches) }\end{array}$} & \multirow{3}{*}{$\begin{array}{c}\text { 1969-2008 } \\
\text { (inches) }\end{array}$} & \multirow{3}{*}{$\begin{array}{c}\text { Percent change } \\
\text { 1915-68 to } \\
\text { 1969-2008 } \\
\text { (inches) }\end{array}$} \\
\hline & & & & & & & & & & \\
\hline & & $\begin{array}{c}\text { P2 } \\
\left(\mathrm{ft}^{3} / \mathrm{s}\right)\end{array}$ & $\begin{array}{l}\text { P100 } \\
\left(\mathrm{ft}^{3} / \mathrm{s}\right)\end{array}$ & $\begin{array}{c}\text { P2 } \\
\left(\mathrm{ft}^{3} / \mathbf{s}\right)\end{array}$ & $\begin{array}{l}\text { P100 } \\
\left(\mathrm{ft}^{3} / \mathrm{s}\right)\end{array}$ & $\begin{array}{c}\text { P2 } \\
\text { (percent) }\end{array}$ & $\begin{array}{c}\text { P100 } \\
\text { (percent) }\end{array}$ & & & \\
\hline \multicolumn{11}{|c|}{ Forested streams } \\
\hline 04071000 & $\begin{array}{l}\text { Oconto River near } \\
\text { Gillett }\end{array}$ & 2,560 & 6,980 & 2,170 & 4,670 & -15 & -33 & 29.8 & 31.3 & 5 \\
\hline 05333500 & $\begin{array}{l}\text { St. Croix River near } \\
\text { Danbury }\end{array}$ & 4,610 & 12,200 & 4,920 & 10,700 & 7 & -12 & 29.8 & 31.7 & 6 \\
\hline 04027000 & $\begin{array}{l}\text { Bad River near } \\
\text { Odanah }\end{array}$ & 7,950 & 26,600 & 7,230 & 20,300 & -9 & -24 & 31.6 & 32.1 & 2 \\
\hline 05394500 & $\begin{array}{l}\text { Prairie River near } \\
\quad \text { Merrill }\end{array}$ & 1,410 & 4,990 & 1,420 & 3,040 & 1 & -39 & 31.1 & 31.8 & 2 \\
\hline 05362000 & $\begin{array}{l}\text { Jump River at } \\
\text { Sheldon }\end{array}$ & 16,000 & 27,800 & 8,200 & 19,800 & -49 & -29 & 31.7 & 32.1 & 1 \\
\hline \multicolumn{4}{|c|}{ Average for five gaging stations } & & & -13 & -27 & & & 3 \\
\hline \multicolumn{11}{|c|}{ Agricultural streams } \\
\hline 05410490 & $\begin{array}{l}\text { Kickapoo River at } \\
\text { Steuben }\end{array}$ & 3,500 & 14,800 & 2,240 & 16,200 & -36 & 9 & 31.7 & 34.1 & 8 \\
\hline 05379500 & $\begin{array}{l}\text { Trempealeau River } \\
\text { at Dodge }\end{array}$ & 4,290 & 18,000 & 3,200 & 12,500 & -25 & -31 & 30.3 & 33.2 & 10 \\
\hline 05414000 & $\begin{array}{l}\text { Platte River near } \\
\text { Rockville }\end{array}$ & 5,170 & 31,200 & 2,340 & 17,700 & -55 & -43 & 32.1 & 34.4 & 7 \\
\hline 04073500 & Fox River at Berlin & 3,540 & 8,240 & 3,120 & 6,930 & -12 & -16 & 30.7 & 32.8 & 7 \\
\hline 05399500 & $\begin{array}{l}\text { Big Eau Pleine } \\
\text { River near Strat- } \\
\text { ford }\end{array}$ & 7,900 & 29,400 & 7,510 & 22,800 & -5 & -22 & 31.8 & 32.1 & 1 \\
\hline 04087000 & $\begin{array}{l}\text { Milwaukee River at } \\
\text { Milwaukee }\end{array}$ & 4,540 & 14,400 & 4,840 & 14,600 & 7 & 1 & 29.9 & 32.8 & 10 \\
\hline 05436500 & $\begin{array}{l}\text { Sugar River at } \\
\text { Brodhead }\end{array}$ & 3,730 & 16,000 & 2,550 & 9,260 & -32 & -42 & 31.3 & 34.4 & 10 \\
\hline 05545750 & $\begin{array}{l}\text { Fox River near New } \\
\text { Munster }\end{array}$ & 2,490 & 7,630 & 2,980 & 6,840 & 20 & -10 & 30.8 & 34.0 & 11 \\
\hline 05426000 & $\begin{array}{l}\text { Crawfish River at } \\
\text { Milford }\end{array}$ & 2,170 & 6,200 & 2,280 & 6,310 & 5 & 2 & 31.3 & 34.4 & 10 \\
\hline 05430500 & Rock River at Afton & 6,400 & 15,400 & 6,390 & 15,300 & 0 & -1 & 30.9 & 34.1 & 10 \\
\hline \multicolumn{4}{|c|}{ Average for nine gaging stations* } & & & -13 & -15 & & & 8.2 \\
\hline \multicolumn{4}{|c|}{ Average for 14 gaging stations* } & & & -14 & -21 & & & 6.5 \\
\hline
\end{tabular}

${ }^{*}$ Note: Rock River at Afton not included in averages since Crawfish River is in the Rock River at Afton drainage area. 


